\title{
The Effects of Angiotensin II on Renal Water and Elec- trolyte Excretion in Normal and Caval Dogs*
}

\author{
Jerome G. Porush, George J. Kaloyanides, $\$$ Roy J. Cacciaguida, and \\ StANLEy M. Rosen $\ddagger$ \\ (From the Department of Medicine, The Brookdale Hospital Center, Maimonides Hospital of \\ Brooklyn, and State University of New York, Downstate Medical Center, \\ Brooklyn, New York)
}

\begin{abstract}
The effects of intravenous administration of angiotensin II on renal water and electrolyte excretion were examined during hydropenia, water diuresis, and hypotonic saline diuresis in anesthetized normal dogs and dogs with thoracic inferior vena cava constriction and ascites (caval dogs). The effects of unilateral renal artery infusion of a subpressor dose were also examined.

During hydropenia angiotensin produced a decrease in tubular sodium reabsorption, with a considerably greater natriuresis in caval dogs, and associated with a decrease in free water reabsorption $\left(\mathrm{T}^{\mathrm{c}}{ }_{\mathrm{H}_{2} \mathrm{O}}\right)$. Water and hypotonic saline diuresis resulted in an augmented angiotensin natriuresis, with a greater effect still observed in caval dogs. In these experiments free water excretion $\left(\mathrm{C}_{\mathrm{H}_{2} \mathrm{O}}\right)$ was limited to $8-10 \%$ of the glomerular filtration rate (GFR), although distal sodium load increased in every instance. In the renal artery infusion experiments a significant ipsilateral decrease in tubular sodium reabsorption was induced, particularly in caval dogs.

These findings indicate that angiotensin has a direct effect on renal sodium reabsorption unrelated to a systemic circulatory alteration. The attenuation or prevention of the falls in GFR and effective renal plasma flow (ERPF) usually induced by angiotensin may partially account for the greater natriuretic response in caval dogs and the augmentation during water or hypotonic saline diuresis. However, a correlation between renal hemodynamics and the degree of natriuresis induced was not always present and, furthermore, GFR and ERPF decreased significantly during the intrarenal artery infusion experiments. Therefore, the present experiments indicate that another mechanism is operative in the control of the angiotensin natriuresis and suggest that alterations in intrarenal hemodynamics may play a role.

The decrease in $\mathrm{T}^{\mathrm{c}} \mathrm{H}_{2} \mathrm{O}$ and the apparent limitation of $\mathrm{C}_{\mathrm{H}_{2} \mathrm{O}}$ associated with an increase in distal sodium load localize the site of action of angiotensin to the ascending limb of Henle's loop and the proximal tubule.
\end{abstract}

\section{Introduction}

It has been demonstrated by numerous investigators that angiotensin II can decrease renal tubular sodium reabsorption in various experimental

* Received for publication 10 April 1967 and in revised form 17 August 1967.

This investigation was supported by grants HE-07839 and HE-10914, from the National Heart Institute, $\mathrm{Na}$ tional Institutes of Health, Bethesda, Md. Presented, in animals independent of its effect on glomerular filtration rate (1-8). In normal man angiotensin

part, at the Third International Congress of Nephrology, 25-30 September 1966, Washington, D. C.

$¥$ Work performed during the tenure of a U. S. Public Health Service postdoctoral research fellowship.

Address requests for reprints to Dr. Jerome G. Porush, Department of Medicine, Brookdale Hospital Center, Linden Boulevard and Rockaway Parkway, Brooklyn, N. Y. 11212. 
administration is associated with sodium retention, which is generally accounted for by a decrease in glomerular filtration rate $(9,10)$. In contrast, angiotensin many induce a natriuresis in patients with renovascular or malignant hypertension (1013 ) or cirrhosis with ascites (9). In normal dogs the administration of angiotensin may be associated with either an increase or decrease in renal sodium excretion, depending upon the dose and such experimental conditions as the use of anesthesia or the presence of an osmotic diuresis $(5,7,8,14$, $15)$. Preliminary experiments reported from this laboratory have demonstrated that dogs with thoracic inferior vena cava constriction and ascites (caval dogs) have a considerably greater natriuretic response to angiotensin than normal dogs $(16,17)$. This finding is also suggested in the report of Cannon et al. (14).

In the present experiments the difference in the natriuretic response of normal and caval dogs to the intravenous infusion of a pressor dose of angiotensin was examined under various experimental conditions by standard clearance techniques in an attempt to delineate the factors that influence the magnitude of this response. In addition, a subpressor dose of angiotensin was infused directly into one renal artery of normal and caval dogs in order to evaluate the role of the systemic pressor action on renal sodium excretion more precisely. The tubular site of action of angiotensin was also explored by examining the effects on urine concentration and dilution.

\section{Methods}

All experiments were performed on either normal female dogs or dogs with constriction of the thoracic inferior vena cava and ascites (18) weighing $12-25 \mathrm{~kg}$. All dogs, except those on a low salt diet, were fed a standard kennel ration containing $50-60 \mathrm{mEq}$ of sodium per day. Six groups of experiments were performed under hydropenia or water diuresis.

Hydropenia. Group I consisted of 12 normal and 12 caval dogs. $48 \mathrm{hr}$ before each experiment the animals were deprived of all food and water, and $16 \mathrm{hr}$ before the study each dog received $5 \mathrm{U}$ of vasopressin tannate in oil intramuscularly. All the dogs were anesthetized with sodium pentobarbital $(30 \mathrm{mg} / \mathrm{kg})$ administered intravenously. An endotracheal tube was then inserted and connected to a mechanical respirator supplying $100 \%$ oxygen. The urinary bladder was catheterized with a number 16 Foley catheter and double air washouts were used to insure complete emptying of the bladder. Blood samples were obtained through a Cournand needle secured into a femoral artery. In most of the experiments femoral blood pressure was monitored with a Statham transducer (Statham Instruments, Inc., Los Angeles, Calif.) and Sanborn recorder (Sanborn Co., Waltham, Mass.).

After initial blood and urine samples were obtained, priming doses of inulin and $p$-aminohippurate (PAH) were administered, followed by a sustaining infusion of these substances in $10 \%$ mannitol in amounts calculated to maintain the blood level of inulin at $25 \mathrm{mg} / 100 \mathrm{ml}$ and $\mathrm{PAH}$ at $2 \mathrm{mg} / 100 \mathrm{ml}$. Aqueous pitressin, sufficient to deliver $50 \mathrm{mU} / \mathrm{kg} \mathrm{hr}$, was also added to this infusion which was administered by a constant infusion pump at $3 \mathrm{ml} /$ min. The modest mannitol diuresis was produced during these hydropenic experiments because of the difficulty in interpretation of changes in solute-free water reabsorption $\left(\mathrm{T}^{\mathrm{c}}{ }_{\mathrm{H} 2 \mathrm{O}}\right)$ at very low rates of solute clearance $\left(\mathrm{C}_{\mathrm{osm}}\right)$ (19) and because it permitted the examination of $\mathrm{T}^{\mathrm{e}}{ }_{\mathrm{H}_{\mathbf{O}} \mathrm{O}}$ over a range of Cosm. Urine samples were collected every $10 \mathrm{~min}$ and blood specimens were drawn at appropriate intervals. After achieving a steady state (three 10-min clearance periods with less than $5 \%$ variation in urine flow), angiotensin II ${ }^{1}$ was added to the sustaining infusion in an amount sufficient to deliver $0.1 \mu \mathrm{g} / \mathrm{kg} \mathrm{min}$. Additional urine samples were taken at 10 -min intervals for a minimum of $60 \mathrm{~min}$.

Group II consisted of eight normal and eight caval dogs studied after 1 wk of salt depletion ${ }^{2}$ in a manner similar to that used for group I. Salt depletion was induced by providing a diet containing less than $10 \mathrm{mEq}$ of sodium per day for 7 days along with a daily intramuscular injection of $1 \mathrm{ml}$ of meralluride for the first 4 days of the diet to insure a period of negative sodium balance.

In group III the effects of a progressive mannitol diuresis were examined in nine caval dogs. These animals were prepared as described in group I. After priming doses, appropriate amounts of inulin, PAH, and aqueous pitressin were infused in $0.9 \%$ saline at $0.5 \mathrm{ml} / \mathrm{min}$. After equilibration, $10 \%$ mannitol was infused at progressively increasing rates until a urine flow of $15 \mathrm{ml} / \mathrm{min}$ was attained. Urine and blood samples were taken as previously described.

Water diuresis. In group IV, five normal and eight caval dogs were studied during water diuresis. All food was withdrawn $16 \mathrm{hr}$ before the experiment but water was permitted ad lib. On the morning of the experiment an oral water load amounting to $5 \%$ of body weight was administered by a gastric tube. $1 \mathrm{hr}$ later the animals were anesthetized with $2.5 \%$ sodium pentothal $(1 \mathrm{ml} / \mathrm{kg}$ intravenously). Endotracheal intubation, urinary bladder catheterization and emptying, femoral artery blood sampling, and blood pressure monitoring were performed as described for group I. After initial blood and urine sam-

1 Hypertension-Ciba (1-L asparaginyl-5-1 valyl angiotensin octapeptide), generously supplied by Dr. William E. Wagner, Ciba Pharmaceutical Co., Summit, N. J.

2 Although caval dogs are referred to as "salt depleted," it is understood that the period of negative balance sustained by these animals did not actually lead to salt depletion as occurred in normal dogs. 
ples were obtained, priming doses of inulin and $\mathrm{PAH}$ were administered followed by a sustaining solution of these substances in $0.45 \%$ saline delivered at $0.5 \mathrm{ml} / \mathrm{kg}$ min to maintain a water diuresis. This infusion rate had previously been demonstrated to maintain water diuresis without producing a significant saline diuresis. After achieving a steady state, angiotensin II was added to the sustaining infusion to deliver $0.1 \mu \mathrm{g} / \mathrm{kg} \min$. Urine and blood samples were obtained as outlined above.

In group $\mathrm{V}$, eight normal and five caval dogs were prepared and studied in the same manner as in group IV except that the sustaining solution of $0.45 \%$ saline was infused at the higher rate of $1.25 \mathrm{ml} / \mathrm{kg} \mathrm{min} \mathrm{in}$ order to achieve a saline diuresis.

In group VI, a subpressor dose of angiotensin was infused directly into the left renal artery of five normal and five caval dogs under hydropenic conditions. These animals were prepared as described for group I except that both ureters were catheterized through a midline suprapubic incision and a 23 gauge needle was inserted into the left renal artery exposed via a flank incision. The needle in the renal artery was kept patent by a constant infusion of $0.9 \%$ saline at $0.5 \mathrm{ml} / \mathrm{min}$. Inulin and $\mathrm{PAH}$ primes were administered followed by a sustaining infusion as in group I. After achieving a steady state, angiotensin II was added to the renal artery infusion to deliver $0.01 \mu \mathrm{g} / \mathrm{kg} \mathrm{min}$. Urine samples were then collected from each kidney at 10 -min intervals for a period of 60 $\min$.

All plasma and urine samples were analyzed for osmolality with a Fiske osmometer (Fiske Associates, Inc., Uxbridge, Mass.). Sodium and potassium content were determined with a flame photometer (Baird-Atomic, Inc., Cambridge, Mass. or Instrumentation Laboratory Inc., Boston, Mass.) using lithium as an internal standard. Chloride concentration was determined by the method of Schales and Schales (20) or the titrimetric method of Cotlove et al. (21). Inulin was determined by the method of Schreiner (22) and PAH by the method of Smith et al. (23).
NORMAL DOGS

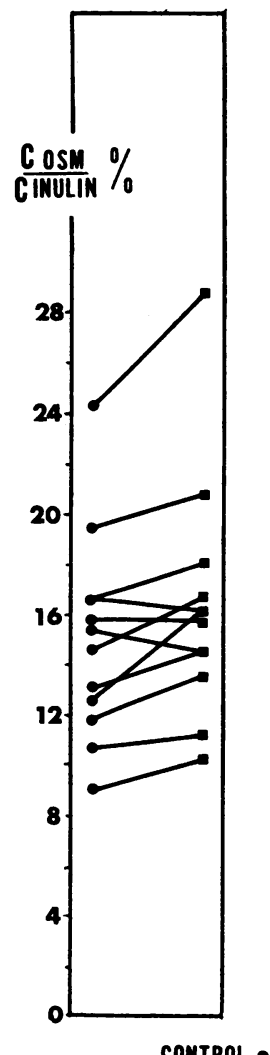

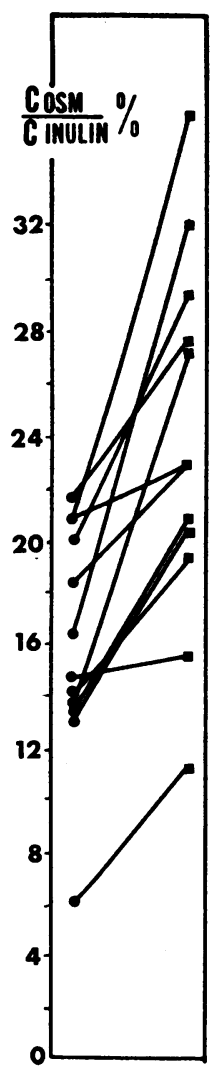

CONTROL
CAYAL DOGS

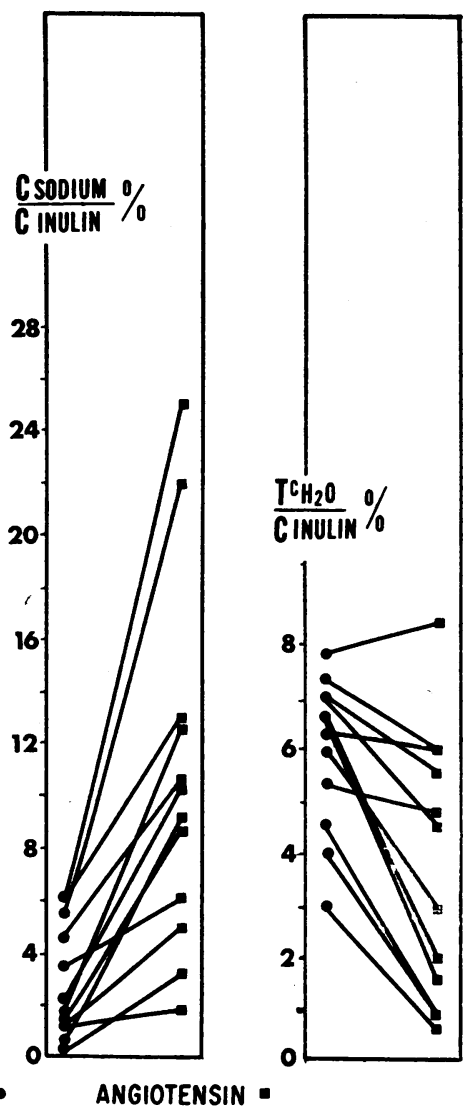

Fig. 1. EFfects of angiotensin II on fractional solute eXCREtion (Cosm/C InUlin), fractional sodium eXCReIION ( $\mathrm{C}_{\text {SODIUM }} / \mathrm{C}_{\text {INULIN }}$ ) AND FRACTIONAL SOLUTE FREE WATER REABSORPTION ( $T_{\text {HoO/C }}{ }_{\text {INULiN }}$ ) IN NORMAL AND CAVAL IHOGS DURING HYDROPENIA. The control represents the average of three steady state periods before angiotensin. The angiotensin period represents the period of maximal sodium excretion after angiotensin. The control and angiotensin period from individual experiments are joined. 
Glomerular filtration rate (GFR) and effective renal plasma flow (ERPF) were calculated as the clearance of inulin and $\mathrm{PAH}$, respectively. $\mathrm{C}_{\text {osm }}$ was calculated from the equation $C_{o s m}=U_{o s m} V / P_{o s m}$, where $U_{o s m}=$ urine osmolality, $\mathrm{V}=$ urine flow, and $\mathrm{P}_{\mathrm{osm}}=$ plasma osmolality. $T^{\mathbf{c}}{ }_{\mathrm{H}_{2} \mathrm{O}}$ was derived from the equation $\mathrm{T}^{\mathrm{c}}{ }_{\mathrm{H}_{2} \mathrm{O}}=$ $\mathrm{C}_{\mathrm{osm}}-\mathrm{V}$. The rate of solute-free water excretion $\left(\mathrm{C}_{\mathrm{H}_{2} \mathrm{O}}\right)$ was derived from the equation $\mathrm{C}_{\mathrm{H}_{2} \mathrm{O}}=\mathrm{V}-\mathrm{C}_{\mathrm{osm}}$. Fractional sodium excretion (per cent of the filtered load of sodium excreted) was calculated as $\mathrm{C}_{\mathrm{Na}} / \mathrm{C}_{\mathrm{In}} \times 100$, where $\mathrm{C}_{\mathrm{Na}}$ represents sodium clearance and $\mathrm{C}_{\mathrm{In}}$, inulin clearance. Similarly, fractional solute excretion, fractional solutefree water reabsorption, and fractional solute-free water excretion were calculated from $C_{\text {osm }} / C_{I n} \times 100, T^{c}{ }_{H=0} /$ $\mathrm{C}_{\mathrm{In}} \times 100$, and $\mathrm{C}_{\mathrm{H}_{2} \mathrm{O}} / \mathrm{C}_{\mathrm{In}} \times 100$, respectively. Fractional distal sodium load was calculated as $\mathrm{C}_{\mathrm{Na}}+\mathrm{C}_{\mathrm{H}_{2} \mathrm{O}} / \mathrm{C}_{\mathrm{In}} \times$ 100. Significance was tested by standard statistical analysis.

\section{Results}

During the first postangiotensin collection period, a decrease in fractional sodium excretion was observed in all the experiments, usually accompanied by a fall in GFR. Thereafter two patterns of response were noted. Either sodium excretion returned toward the control level or a distinct natriuresis was observed with the maximal natriuretic effect occurring 20-30 min after the start of

TABLE I

Summary of effects of angiotensin II under hydropenic conditions*

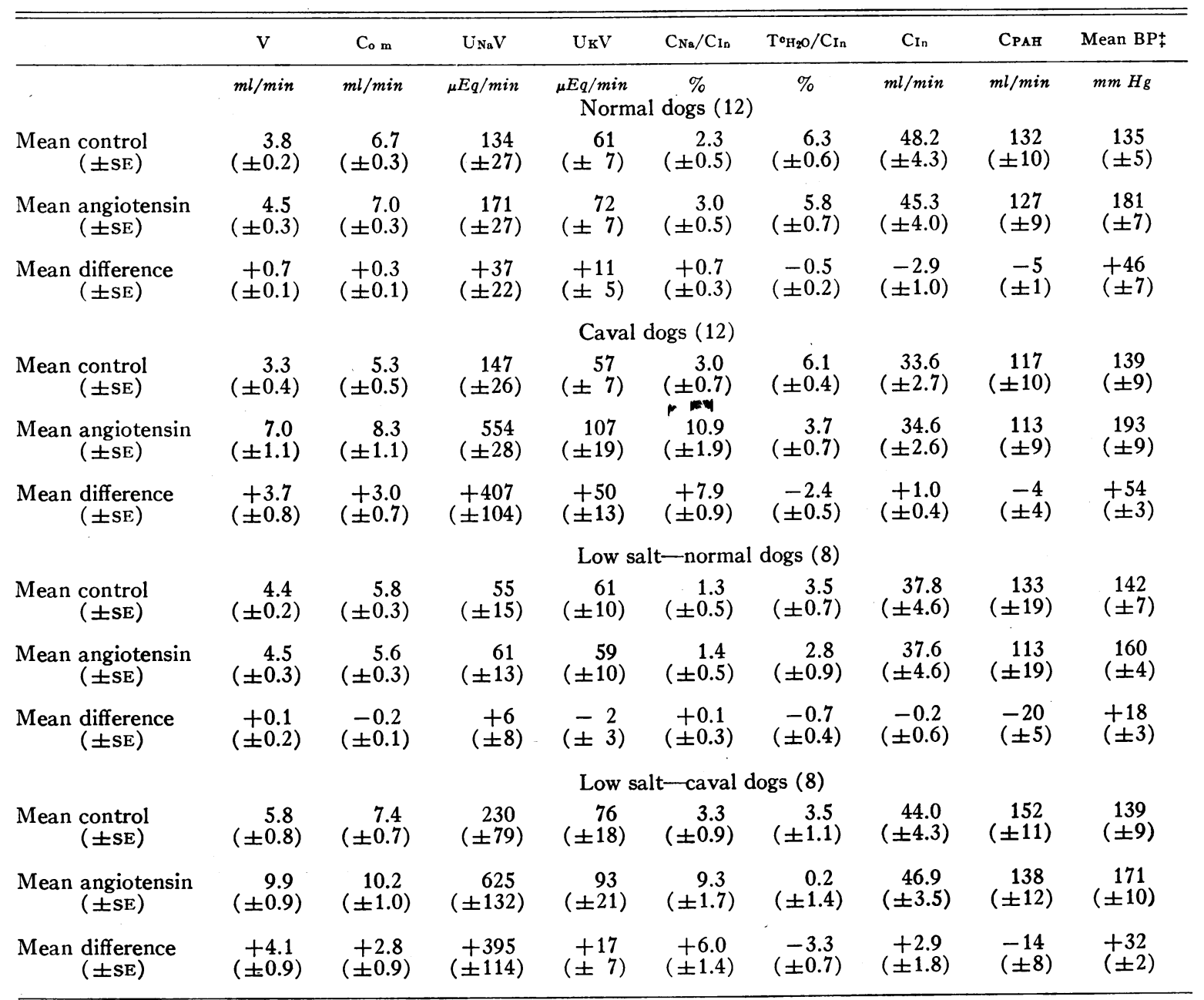

*V $\mathrm{V}$, urine flow $; \mathrm{C}_{\mathrm{osm}}$, solute clearance; $\mathrm{U}_{\mathrm{Na}} \mathrm{V}$, sodium excretion; $\mathrm{U}_{\mathrm{K}} \mathrm{V}$, potassium excretion; $\mathrm{C}_{\mathrm{Na}} / \mathrm{C}_{\mathrm{In}}$, sodium to inulin

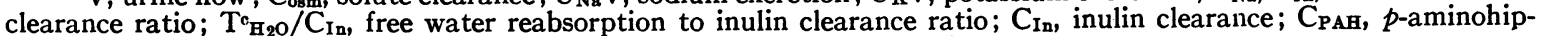
purate clearance; Mean BP, mean blood pressure; SE, standard error of the mean.

$\ddagger$ The mean blood pressure for the angiotensin period represents the maximal mean blood pressure observed in response to angiotensin and not the blood pressure recorded during the period of maximal sodium excretion. 
LOW SALT-NORMAL DOGS
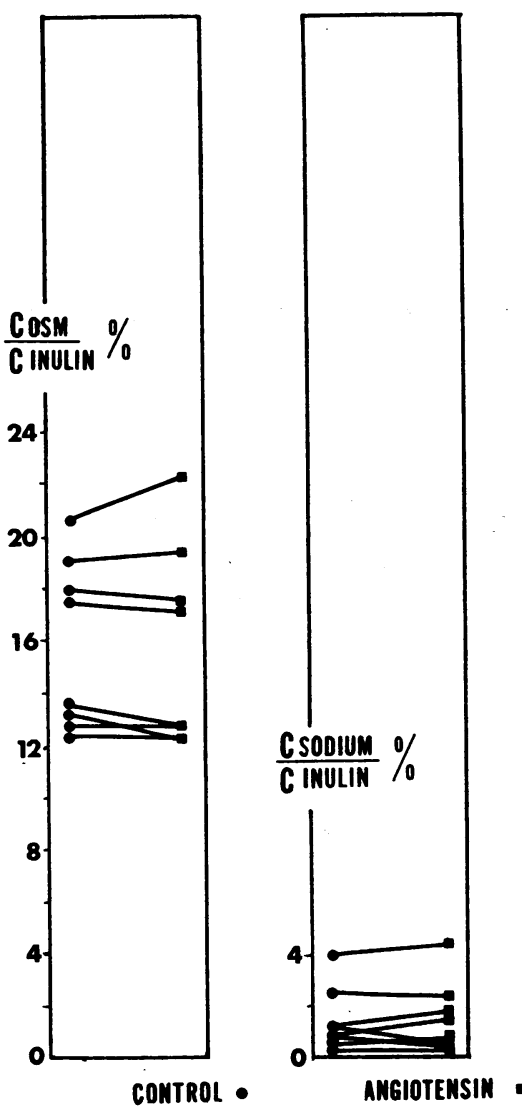

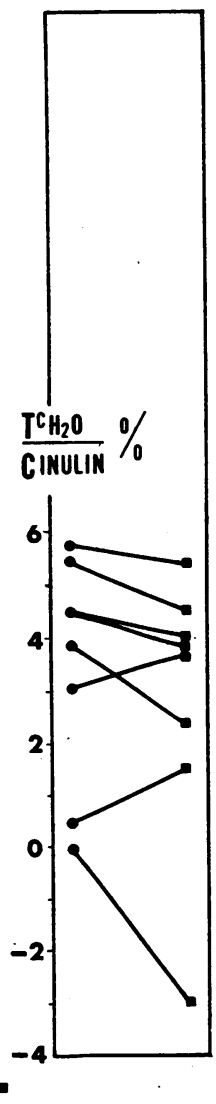

LOW SALT - CAYAL DOGS

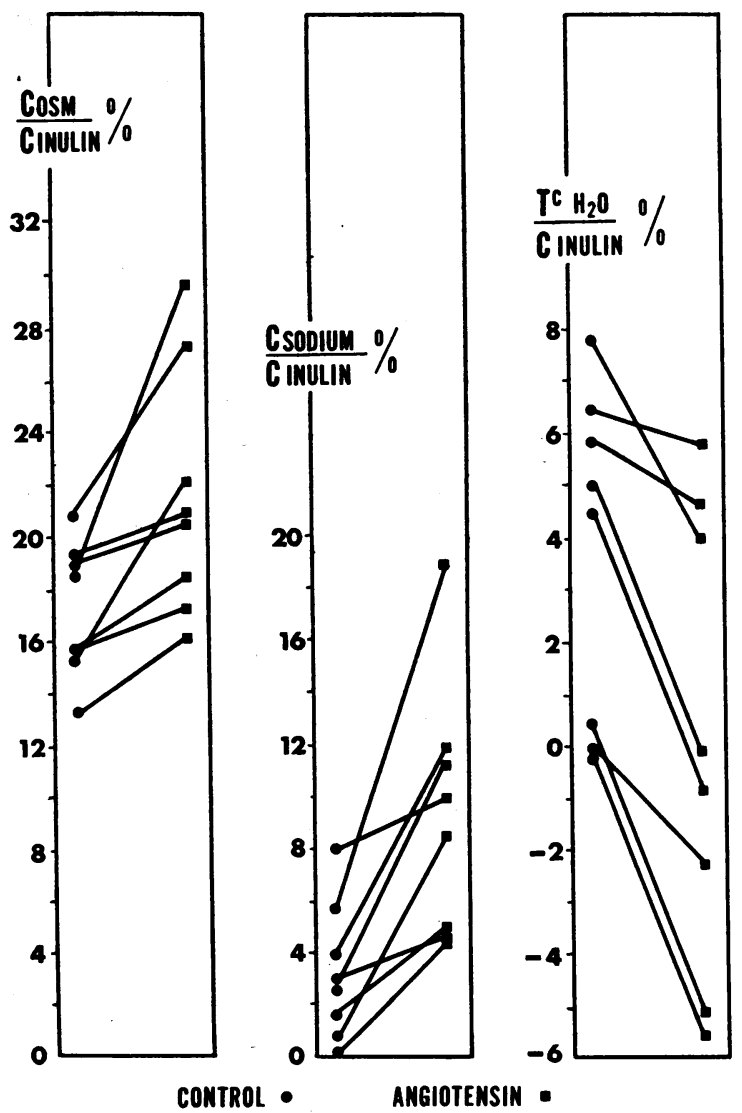

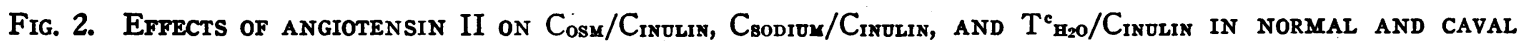
DOGS DURING HYDROPENIA AFTER SALT RESTRICTION. The control and angiotensin periods are defined as in Fig 1.

the angiotensin infusion. In all experiments a rise in blood pressure was noted within $60 \mathrm{sec}$ after the angiotensin infusion and reached a peak at approximately 5-7 min. Thereafter the blood pressure very gradually declined but never returned to control level while the angiotensin infusion was continued. The data were analyzed by comparing the control with the clearance period of maximal sodium excretion after angiotensin. The angiotensin period referred to in the text, tables, and figures represents the period of maximal sodium excretion after angiotensin. The control represents the mean of three steady state collection periods immediately before the infusion of angiotensin. The results described below are expressed as the mean of all controls and peak angiotensin periods for each experimental group. When discussing fractional excretion, the changes represent per cent of GFR. In all other situations the changes represent per cent of initial value.
Hydropenia. These results are summarized in Fig. 1 and Table I. Angiotensin produced a slight natriuresis in 10 of 12 normal dogs fed a regular salt diet. $\mathrm{U}_{\mathrm{Na}} \mathrm{V}$ increased $37 \mu \mathrm{Eq} / \mathrm{min}$ and $\mathrm{C}_{\mathrm{Na}} /$ $\mathrm{C}_{\text {In }}$ increased $0.7 \%$. In contrast, all 12 caval dogs had a marked natriuretic response to angiotensin with $\mathrm{U}_{\mathrm{Na}} \mathrm{V}$ increasing $407 \mu \mathrm{Eq} / \mathrm{min}$ and $\mathrm{C}_{\mathrm{Na}} / \mathrm{C}_{\mathrm{In}}$ increasing $7.9 \% . \quad \mathrm{T}^{\mathrm{e}_{2} \mathrm{O}} / \mathrm{C}_{\mathrm{In}}$ decreased $0.5 \%$ and $2.4 \%$ in normal and caval dogs, respectively. $\mathrm{C}_{\text {In }}$ decreased a mean of $4.1 \%$ in normal and increased a mean of $3.1 \%$ in caval dogs. $\mathrm{C}_{\mathrm{PAH}}$ decreased slightly in both groups, $3.8 \%$ in normal and $3.4 \%$ in caval dogs. Mean blood pressure increased 46 $\mathrm{mm}$ mercury in normal dogs and $54 \mathrm{~mm}$ mercury in caval dogs.

Hydropenia-salt depletion. These results are summarized in Fig. 2 and Table I. With salt restriction both groups of animals sustained a $10 \%$ decrease in body weight. In normal dogs there was a loss of the natriuretic response to angio- 
tensin, whereas in caval dogs a brisk natriuresis was still evident although the increase in $\mathrm{C}_{\mathrm{Na}} / \mathrm{C}_{\mathrm{In}}$ of $6.0 \%$ was slightly less than the $7.9 \%$ increase obtained in caval dogs on a regular salt intake. This difference was not statistically significant $(P>0.3)$. $\quad \mathrm{T}_{\mathbf{H}_{2} \mathbf{O}}^{\mathbf{O}}$ decreased slightly in normal dogs, whereas a marked fall in $\mathrm{T}^{\mathrm{c}}{ }_{\mathrm{H}_{2} \mathrm{O}}$ occurred in caval dogs with five of the eight animals excreting a dilute urine. $\mathrm{C}_{\mathrm{In}}$ did not change in normal dogs and increased $6.5 \%$ in caval dogs. $\mathrm{C}_{\mathrm{PAH}}$ decreased in both groups, $15 \%$ in normal dogs and $9.2 \%$ in caval dogs. Salt restriction resulted in a marked reduction in the pressor response to angiotensin in both normal and caval dogs, with mean blood pressure increasing only $18 \mathrm{~mm}$ and $32 \mathrm{~mm}$ mercury, respectively. These responses were significantly lower than in group I $(P<0.05)$.

Progressive mannitol diuresis. In Fig. 3 the pattern of $\mathrm{T}^{\mathbf{c}}{ }_{\mathrm{H}_{2} \mathrm{O}}$ formation in nine caval dogs dur- ing a progressive mannitol diuresis is depicted. As $\mathrm{C}_{\mathrm{osm}}$ increased from nondiuretic levels to $10 \mathrm{ml}$ $/ \mathrm{min}, \mathrm{T}^{\mathrm{c}} \mathrm{H}_{2} \mathrm{O}$ increased from approximately 0.5 to $2.7 \mathrm{ml} / \mathrm{min}$. Thereafter, $\mathrm{T}^{\mathrm{c}} \mathbf{H}_{2} \mathrm{O}$ remained stable as $\mathrm{C}_{\text {osm }}$ increased to $16 \mathrm{ml} / \mathrm{min}$. In the same figure the effect of angiotensin on $\mathrm{T}^{\mathrm{c}} \mathrm{H}_{2} \mathrm{O}$ formation in 12 caval dogs is shown for contrast. In 11 of the 12 experiments the increase in $\mathrm{C}_{\text {osm }}$ associated with angiotensin was accompanied by a fall in $\mathrm{T}^{\mathrm{c}}{ }_{\mathrm{H}_{2} \mathrm{O}}$ over the same range of $\mathrm{C}_{\text {osm }}$ in which $\mathrm{T}^{\mathrm{c}} \mathrm{H}_{2} \mathrm{O}$ increased with mannitol.

Water diuresis. These results are summarized in Fig. 4 and Table II. Although $0.45 \%$ saline was infused to maintain water diuresis, the control $\mathrm{U}_{\text {osm }}$ of $62 \mathrm{mOsm} / \mathrm{kg}$ of $\mathrm{H}_{2} \mathrm{O}$ in normal dogs and of $61 \mathrm{mOsm} / \mathrm{kg}$ of $\mathrm{H}_{2} \mathrm{O}$ in caval dogs, as well as the low control $\mathrm{C}_{\mathrm{Na}} / \mathrm{C}_{\mathrm{In}}$ of $1.0 \%$ and $0.7 \%$, respectively, indicates that a significant saline diuresis was not produced. After angiotensin $\mathrm{C}_{\mathrm{Na}} /$

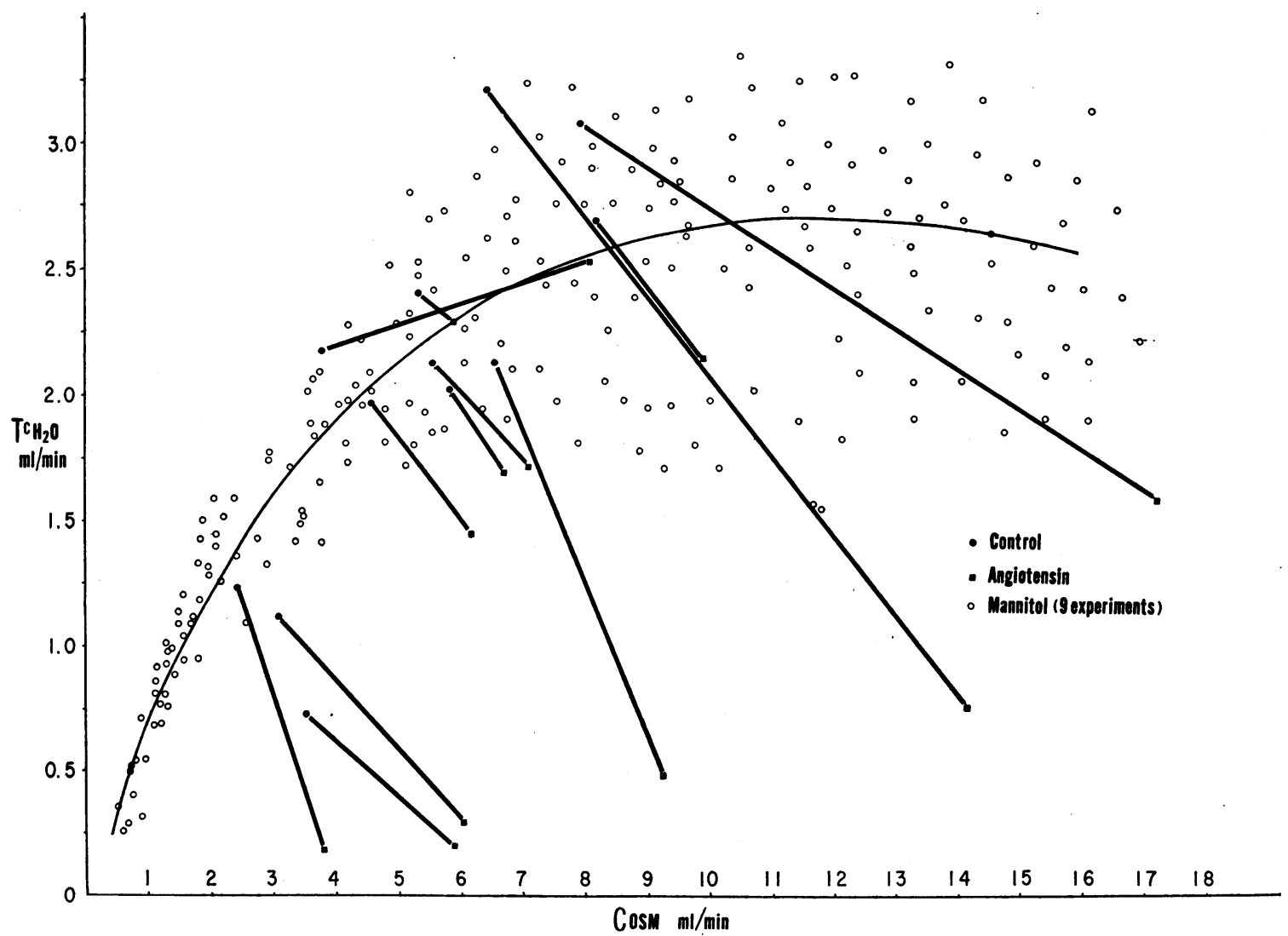

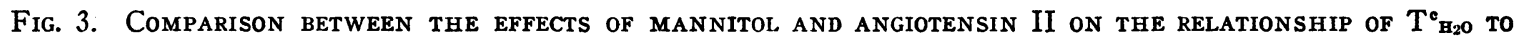
Cosm IN CAVAl Dogs. The open circles represent all the clearance periods during mannitol infusion in nine caval dogs. The thin curved line represents the best fit as determined by inspection. The solid circles and solid squares represent the control and angiotensin periods in 12 caval dogs and are defined as in Fig. 1. 
NORMAL DOGS

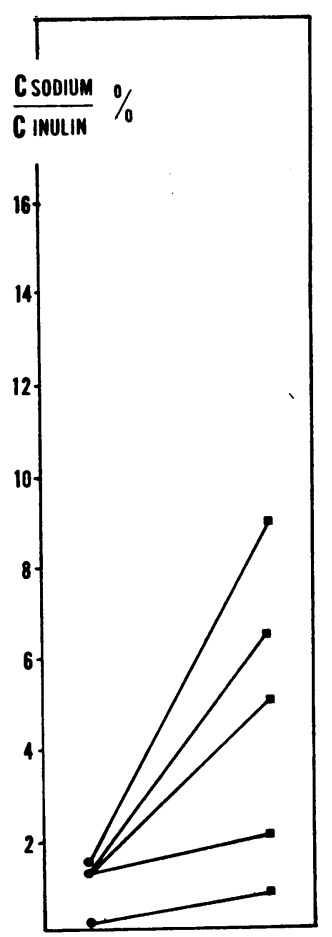

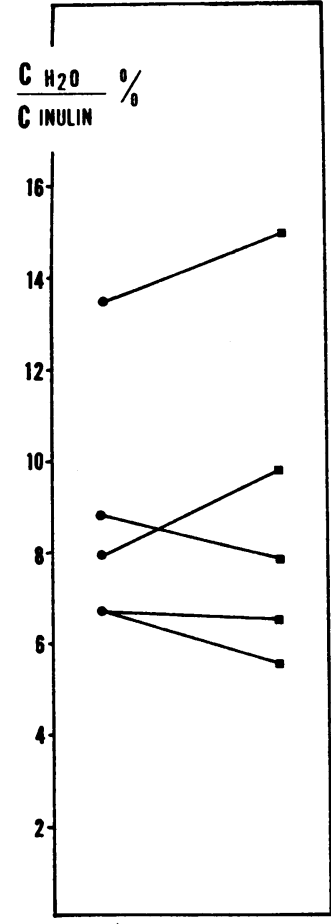

CONTROL •
CAVAL DOGS

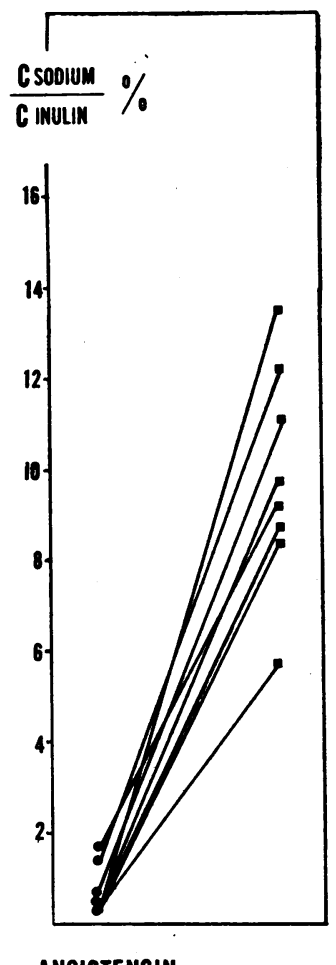

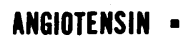

Fig. 4. EFfects of angiotensin II on C Coditm/Cindein and fractional solute free water excretion (C Cinulin) in NORMal aNd CAval dogs during water diUResis. The control and angiotensin periods are defined as in Fig. 1.

$\mathrm{C}_{\text {In }}$ increased $3.7 \%$ in normal and $9.1 \%$ in caval dogs. The greater response in caval compared to normal dogs was highly significant $(P<$ 0.01). Control $\mathrm{C}_{\mathrm{H}_{2} \mathrm{O}} / \mathrm{C}_{\text {In }}$ was $8.7 \%$ in normal and $8.8 \%$ in caval dogs. After angiotensin the change in $\mathrm{C}_{\mathrm{H}_{2} \mathrm{O}} / \mathrm{C}_{\mathrm{In}}$ in both groups of animals was variable, with no mean change in normal dogs but with a decrease of $1.6 \%$ in caval dogs. Examination of the individual responses in caval dogs, however, suggests that if $\mathrm{C}_{\mathrm{H}_{2} \mathrm{O}} / \mathrm{C}_{\text {In }}$ was higher than $8 \%$ during control, it tended to fall after angiotensin, and if below $8 \%$, it tended to rise. $\mathrm{C}_{\text {In }}$ increased $4.4 \%$ in normal dogs and $15.4 \%$ in caval dogs. $\mathrm{C}_{\mathrm{PAH}}$ decreased in both normal and caval dogs, $14.5 \%$ and $3.5 \%$, respectively. Mean blood pressure increased $28 \mathrm{~mm}$ mercury in normal dogs and $41 \mathrm{~mm}$ mercury in caval dogs. After angiotensin fractional distal sodium load increased in both groups, with a greater effect in caval dogs, $7.5 \%$ as against $3.9 \%$.

Hypotonic saline diuresis. These results are summarized in Fig. 5 and Table II. In the normal dogs control $\mathrm{U}_{\text {osm }}$ was $143 \mathrm{mOsm} / \mathrm{kg}$ of $\mathrm{H}_{2} \mathrm{O}$ and control $\mathrm{C}_{\mathrm{Na}} / \mathrm{C}_{\text {In }}$ was $14.0 \%$ In contrast, much less sodium was excreted in caval dogs in response to the same infusion rate; control $U_{\text {osm }}$ was 79 $\mathrm{mOsm} / \mathrm{kg}$ of $\mathrm{H}_{2} \mathrm{O}$ and control $\mathrm{C}_{\mathrm{Na}} / \mathrm{C}_{\mathrm{In}}$ was $5.0 \%$. After angiotensin $\mathrm{C}_{\mathrm{Na}} / \mathrm{C}_{\mathrm{In}}$ increased $8.4 \%$ in normal dogs and $18.2 \%$ in caval dogs. Control $\mathrm{C}_{\mathrm{H}_{2} \mathrm{O}} /$ $\mathrm{C}_{\text {In }}$ was $12.0 \%$ in normal dogs and $14.3 \%$ in caval dogs and in every instance decreased after angiotensin, $3.7 \%$ in normal dogs and $3.8 \%$ in caval dogs. As suggested during water diuresis, angiotensin appeared to limit $\mathrm{C}_{\mathrm{H}_{2} \mathrm{O}}$ to approximately $8-10 \%$ of the filtration rate. $C_{\text {In }}$ increased $8 \%$ in normal dogs and $15.2 \%$ in caval dogs. $\mathrm{C}_{\mathrm{PAH}}$ decreased in normal dogs $11.6 \%$ and increased in caval dogs $3.2 \%$. Mean blood pressure increased $63 \mathrm{~mm}$ mercury in normal dogs and $38 \mathrm{~mm}$ mercury in caval dogs. Fractional distal sodium load increased $4.7 \%$ in normal dogs and $14.4 \%$ in caval dogs. 
In Fig. 6 fractional free water excretion is plotted against fractional distal sodium load in caval dogs during both water and hypotonic saline diuresis. In this graph all the clearance periods before and after angiotensin administration are shown. It is evident that in spite of a marked increase in the amount of sodium reaching the diluting segment (as approximated by distal sodium load), free water excretion is limited to approximately $10 \%$ of the filtration rate after angiotensin.

Renal artery infusion of angiotensin. These results are summarized in Table III and Fig. 7. The infusion of a subpressor dose of angiotensin into the left renal artery of normal dogs resulted in a variable effect on sodium excretion. Three of the five dogs demonstrated an ipsilateral natriuresis, with $\mathrm{C}_{\mathrm{Na}} / \mathrm{C}_{\mathrm{In}}$ increasing $0.6 \%$ for the group, whereas on the control side there was no change in fractional sodium excretion. $\mathrm{T}^{\mathrm{c}_{\mathrm{H}_{2} \mathrm{O}}}$ did not change on either side. In five caval dogs an ipsilateral natriuresis was observed in each instance with $\mathrm{C}_{\mathrm{Na}} / \mathrm{C}_{\mathrm{In}}$ increasing $4.8 \%$. On the control side fractional sodium excretion decreased $0.5 \%$. Associated with the natriuresis on the experimental side, $\mathrm{T}_{\mathrm{H}_{2} \mathrm{O}} \mathrm{O} / \mathrm{C}_{\text {In }}$ decreased $1.4 \%$, whereas it increased $0.8 \%$ on the control side. $\mathrm{C}_{\text {In }}$ de-

TABLE II

Summary of effects of angiotensin II during water and hypotonic saline diuresis*

\begin{tabular}{|c|c|c|c|c|c|c|c|c|c|c|}
\hline & $\mathbf{v}$ & Uosm & $\mathrm{U}_{\mathrm{Na}} \mathrm{V}$ & $\mathrm{UkV}_{\mathrm{K}}$ & $\mathrm{C}_{\mathrm{Na}} / \mathrm{C}_{\mathrm{In}}$ & $\mathrm{C}_{\mathrm{H}_{2} \mathrm{O} / \mathrm{C}_{\mathrm{In}}}$ & $\begin{array}{l}\mathrm{C}_{\mathrm{Na}} / \mathrm{C}_{\text {In }} \dagger \\
\mathrm{C}_{\mathrm{H}_{2} \mathrm{O}} / \mathrm{C}_{\mathrm{In}} \ddagger\end{array}$ & $\mathrm{C}_{\mathbf{I n}_{\mathbf{n}}}$ & $\mathrm{C}_{\mathrm{PAH}}$ & Mean BP§ \\
\hline & $m l / m i n$ & $\mathrm{mOsm} / \mathrm{kg}$ & $\mu E q / \min$ & $\begin{array}{l}\mu E q / \min \\
\text { Water }\end{array}$ & $\stackrel{\%}{\text { diuresis- }}$ & $\begin{array}{c}\% \\
\text {-normal }\end{array}$ & $\begin{array}{c}\% \\
\text { logs }(5)\end{array}$ & $\mathrm{ml} / \mathrm{min}$ & $m l / m i n$ & $m m \mathrm{Hg}$ \\
\hline $\begin{array}{c}\text { Mean control } \\
\qquad( \pm \mathrm{SE})\end{array}$ & $\begin{array}{c}8.0 \\
( \pm 1.0)\end{array}$ & $\left(\begin{array}{c}62 \\
\pm 5)\end{array}\right.$ & $\begin{array}{c}105 \\
( \pm 31)\end{array}$ & $\begin{array}{c}51 \\
( \pm 17)\end{array}$ & $\begin{array}{c}1.0 \\
( \pm 0.2)\end{array}$ & $\begin{array}{c}8.7 \\
( \pm 1.3)\end{array}$ & $\begin{array}{c}9.7 \\
( \pm 1.4)\end{array}$ & $\begin{array}{c}75.6 \\
( \pm 12.4)\end{array}$ & $\begin{array}{c}227 \\
( \pm 22)\end{array}$ & $\begin{array}{c}158 \\
( \pm 5)\end{array}$ \\
\hline $\begin{array}{c}\text { Mean angiotensin } \\
( \pm \mathrm{SE})\end{array}$ & $\begin{array}{c}11.4 \\
( \pm 1.6)\end{array}$ & $\begin{array}{c}112 \\
( \pm 16)\end{array}$ & $\begin{array}{c}529 \\
( \pm 195)\end{array}$ & $\begin{array}{c}74 \\
( \pm 16)\end{array}$ & $\begin{array}{c}4.7 \\
( \pm 1.5)\end{array}$ & $\begin{array}{c}8.9 \\
( \pm 1.7)\end{array}$ & $\begin{array}{c}13.6 \\
( \pm 1.8)\end{array}$ & $\begin{array}{c}78.9 \\
( \pm 12.4)\end{array}$ & $\begin{array}{c}194 \\
( \pm 23)\end{array}$ & $\begin{array}{c}186 \\
( \pm 10)\end{array}$ \\
\hline \multirow[t]{2}{*}{$\begin{array}{l}\text { Mean difference } \\
( \pm \mathrm{SE})\end{array}$} & $\begin{array}{c}+3.4 \\
( \pm 1.0)\end{array}$ & $\begin{array}{c}+50 \\
( \pm 18)\end{array}$ & $\begin{array}{c}+424 \\
( \pm 166)\end{array}$ & $\begin{array}{l}+23 \\
( \pm 6)\end{array}$ & $\begin{array}{l}+3.7 \\
( \pm 1.1)\end{array}$ & $\begin{array}{l}+0.2 \\
( \pm 0.6)\end{array}$ & $\begin{array}{l}+3.9 \\
(+1.1)\end{array}$ & $\begin{array}{l}+3.3 \\
( \pm 1.1)\end{array}$ & $\begin{array}{l}-33 \\
( \pm 9)\end{array}$ & $\begin{array}{l}+28 \\
( \pm 11)\end{array}$ \\
\hline & \multicolumn{10}{|c|}{ Water diuresis—caval dogs (8) } \\
\hline $\begin{array}{c}\text { Mean control } \\
( \pm \mathrm{SE})\end{array}$ & $\begin{array}{c}6.7 \\
( \pm 0.8)\end{array}$ & $\begin{array}{c}61 \\
( \pm 9)\end{array}$ & $\begin{array}{c}64 \\
( \pm 19)\end{array}$ & $\begin{array}{c}23 \\
( \pm 3)\end{array}$ & $\begin{array}{c}0.7 \\
( \pm 0.2)\end{array}$ & $\begin{array}{c}8.8 \\
( \pm 1.2)\end{array}$ & $\begin{array}{c}9.5 \\
( \pm 1.3)\end{array}$ & $\begin{array}{c}62.3 \\
( \pm 5.2)\end{array}$ & $\begin{array}{c}174 \\
( \pm 21)\end{array}$ & $\begin{array}{c}147 \\
( \pm 10)\end{array}$ \\
\hline $\begin{array}{c}\text { Mean angiotensin } \\
( \pm \mathrm{SE})\end{array}$ & $\begin{array}{c}12.9 \\
( \pm 1.5)\end{array}$ & $\begin{array}{c}168 \\
( \pm 40)\end{array}$ & $\begin{array}{c}1009 \\
( \pm 159)\end{array}$ & $\begin{array}{c}80 \\
( \pm 10)\end{array}$ & $\begin{array}{c}9.8 \\
( \pm 0.9)\end{array}$ & $\begin{array}{r}7.2 \\
( \pm 1.1)\end{array}$ & $\begin{array}{c}17.0 \\
( \pm 1.2)\end{array}$ & $\begin{array}{c}71.9 \\
( \pm 6.2)\end{array}$ & $\begin{array}{c}168 \\
( \pm 19)\end{array}$ & $\begin{array}{c}188 \\
( \pm 12)\end{array}$ \\
\hline \multirow[t]{2}{*}{$\begin{array}{l}\text { Mean difference } \\
\qquad( \pm \mathrm{SE})\end{array}$} & $\begin{array}{l}+6.2 \\
( \pm 1.5)\end{array}$ & $\begin{array}{l}+107 \\
( \pm 17)\end{array}$ & $\begin{array}{c}+945 \\
( \pm 152)\end{array}$ & $\begin{array}{c}+57 \\
( \pm 10)\end{array}$ & $\begin{array}{l}+9.1 \\
( \pm 0.8)\end{array}$ & $\begin{array}{l}-1.6 \\
( \pm 1.5)\end{array}$ & $\begin{array}{l}+7.5 \\
( \pm 1.7)\end{array}$ & $\begin{array}{c}+9.6 \\
( \pm 3.3)\end{array}$ & $\begin{array}{c}-6 \\
( \pm 10)\end{array}$ & $\begin{array}{l}+41 \\
( \pm 7)\end{array}$ \\
\hline & & \multicolumn{9}{|c|}{ Hypotonic saline diuresis-normal dogs (8) } \\
\hline $\begin{array}{l}\text { Mean control } \\
\qquad( \pm \mathrm{SE})\end{array}$ & $\begin{array}{c}18.5 \\
( \pm 2.7)\end{array}$ & $\begin{array}{c}143 \\
( \pm 11)\end{array}$ & $\begin{array}{c}1254 \\
( \pm 249)\end{array}$ & $\begin{array}{c}60 \\
( \pm 13)\end{array}$ & $\begin{array}{c}14.0 \\
( \pm 2.5)\end{array}$ & $\begin{array}{c}12.0 \\
( \pm 0.3)\end{array}$ & $\begin{array}{c}26.0 \\
( \pm 2.5)\end{array}$ & $\begin{array}{c}67.3 \\
( \pm 6.3)\end{array}$ & $\begin{array}{c}178 \\
( \pm 15)\end{array}$ & $\begin{array}{c}157 \\
( \pm 6)\end{array}$ \\
\hline $\begin{array}{c}\text { Mean angiotensin } \\
( \pm \mathrm{SE})\end{array}$ & $\begin{array}{c}24.1 \\
( \pm 3.1)\end{array}$ & $\begin{array}{c}198 \\
( \pm 8)\end{array}$ & $\begin{array}{c}2148 \\
( \pm 327)\end{array}$ & $\begin{array}{c}89 \\
( \pm 12)\end{array}$ & $\begin{array}{c}22.4 \\
( \pm 2.1)\end{array}$ & $\begin{array}{c}8.3 \\
( \pm 0.6)\end{array}$ & $\begin{array}{c}30.7 \\
( \pm 2.0)\end{array}$ & $\begin{array}{c}72.7 \\
( \pm 7.4)\end{array}$ & $\begin{array}{c}159 \\
( \pm 18)\end{array}$ & $\begin{array}{c}220 \\
( \pm 6)\end{array}$ \\
\hline \multirow[t]{2}{*}{$\begin{array}{c}\text { Mean difference } \\
( \pm \text { SE })\end{array}$} & $\begin{array}{l}+5.6 \\
( \pm 0.7)\end{array}$ & $\begin{array}{l}+55 \\
( \pm 6)\end{array}$ & $\begin{array}{l}+894 \\
( \pm 193)\end{array}$ & $\begin{array}{l}+29 \\
( \pm 9)\end{array}$ & $\begin{array}{l}+8.4 \\
( \pm 0.8)\end{array}$ & $\begin{array}{c}-3.7 \\
( \pm 0.6)\end{array}$ & $\begin{array}{l}+4.7 \\
( \pm 1.2)\end{array}$ & $\begin{array}{l}+5.4 \\
( \pm 2.0)\end{array}$ & $\begin{array}{l}-19 \\
( \pm 7)\end{array}$ & $\begin{array}{l}+63 \\
( \pm 4)\end{array}$ \\
\hline & & \multicolumn{9}{|c|}{ Hypotonic saline diuresis - caval dogs (5) } \\
\hline $\begin{array}{l}\text { Mean control } \\
( \pm \mathrm{SE})\end{array}$ & $\begin{array}{c}11.4 \\
( \pm 1.1)\end{array}$ & $\begin{array}{c}79 \\
( \pm 9)\end{array}$ & $\begin{array}{c}351 \\
( \pm 113)\end{array}$ & $\begin{array}{c}75 \\
( \pm 20)\end{array}$ & $\begin{array}{r}5.0 \\
( \pm 1.4)\end{array}$ & $\begin{array}{c}14.3 \\
( \pm 0.9)\end{array}$ & $\begin{array}{c}19.3 \\
( \pm 2.0)\end{array}$ & $\begin{array}{c}57.4 \\
( \pm 6.4)\end{array}$ & $\begin{array}{c}149 \\
( \pm 20)\end{array}$ & $\begin{array}{c}128 \\
( \pm 9)\end{array}$ \\
\hline $\begin{array}{c}\text { Mean angiotensin } \\
( \pm \mathrm{SE})\end{array}$ & $\begin{array}{c}20.0 \\
( \pm 2.0)\end{array}$ & $\begin{array}{c}178 \\
( \pm 8)\end{array}$ & $\begin{array}{c}1946 \\
( \pm 151)\end{array}$ & $\begin{array}{c}116 \\
( \pm 25)\end{array}$ & $\begin{array}{c}23.2 \\
( \pm 2.9)\end{array}$ & $\begin{array}{c}10.5 \\
( \pm 1.2)\end{array}$ & $\begin{array}{c}33.7 \\
( \pm 3.9)\end{array}$ & $\begin{array}{c}66.1 \\
( \pm 5.4)\end{array}$ & $\begin{array}{c}153 \\
( \pm 20)\end{array}$ & $\begin{array}{c}166 \\
( \pm 8)\end{array}$ \\
\hline $\begin{array}{l}\text { Mean difference } \\
\qquad( \pm \mathrm{SE})\end{array}$ & $\begin{array}{l}+8.8 \\
( \pm 2.4)\end{array}$ & $\begin{array}{l}+99 \\
( \pm 10)\end{array}$ & $\begin{array}{l}+1595 \\
( \pm 234)\end{array}$ & $\begin{array}{l}+41 \\
( \pm 13)\end{array}$ & $\begin{array}{l}+18.2 \\
( \pm 3.5)\end{array}$ & $\begin{array}{l}-3.8 \\
( \pm 0.9)\end{array}$ & $\begin{array}{l}+14.4 \\
( \pm 4.3)\end{array}$ & $\begin{array}{c}+8.7 \\
( \pm 2.8)\end{array}$ & $\begin{array}{c}+4 \\
( \pm 6)\end{array}$ & $\begin{array}{l}+38 \\
( \pm 2)\end{array}$ \\
\hline
\end{tabular}

${ }^{*} \mathrm{U}_{\mathrm{osm}}$, urine osmolality; $\mathrm{C}_{\mathrm{H}_{2} \mathrm{O}} / \mathrm{C}_{\mathrm{In}}$, free water to inulin clearance ratio; other abbreviations are the same as in Table $\mathrm{I}$. $\ddagger$ Represents an approximation of fractional distal sodium load.

$\S$ The mean blood pressure for the angiotensin period represents the maximal mean blood pressure observed in response to angiotensin and not the blood pressure recorded during the period of maximal sodium excretion. 
NORMAL DOGS
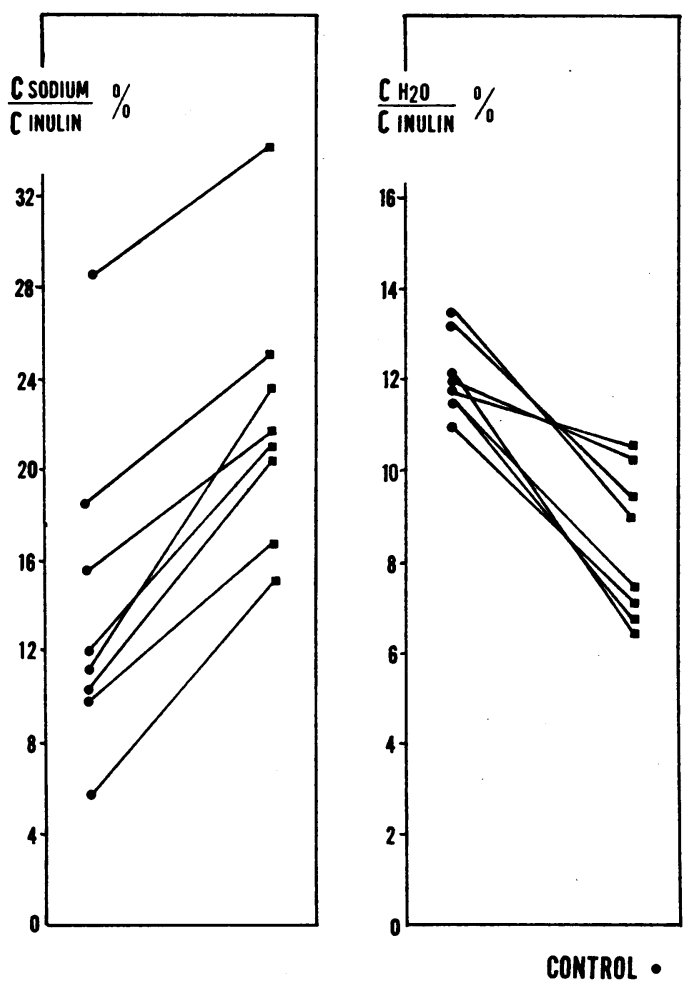

CAVAL DOGS
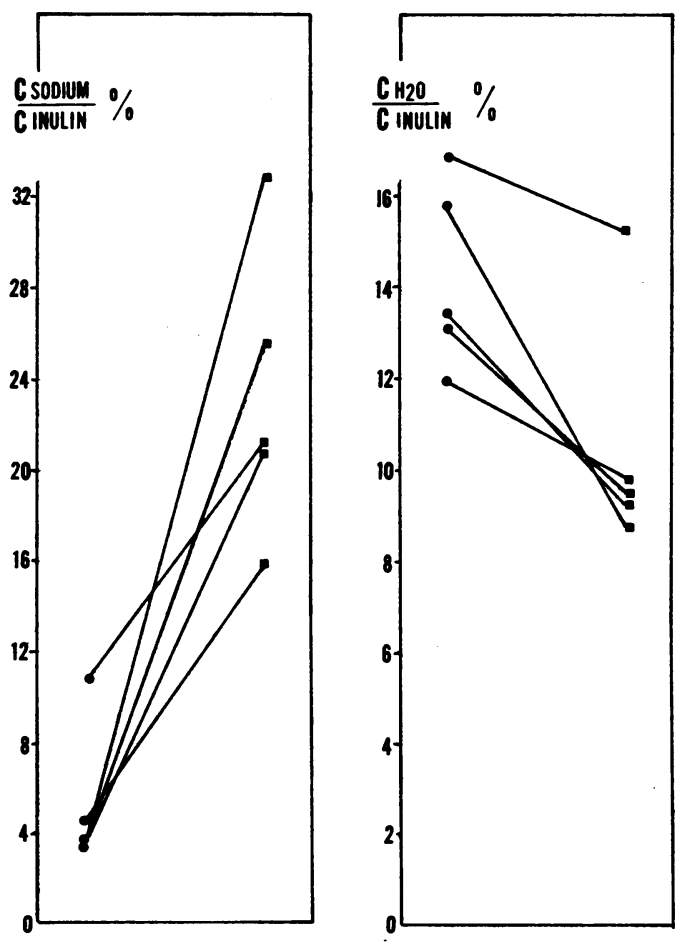

\section{ANGIOTENSIN -}

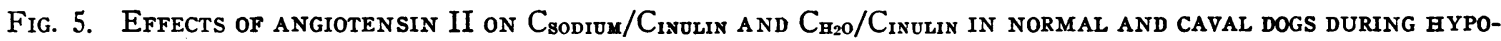
TONIC SALINE DIURESIS. The control and angiotensin periods are defined as in Fig. 1.

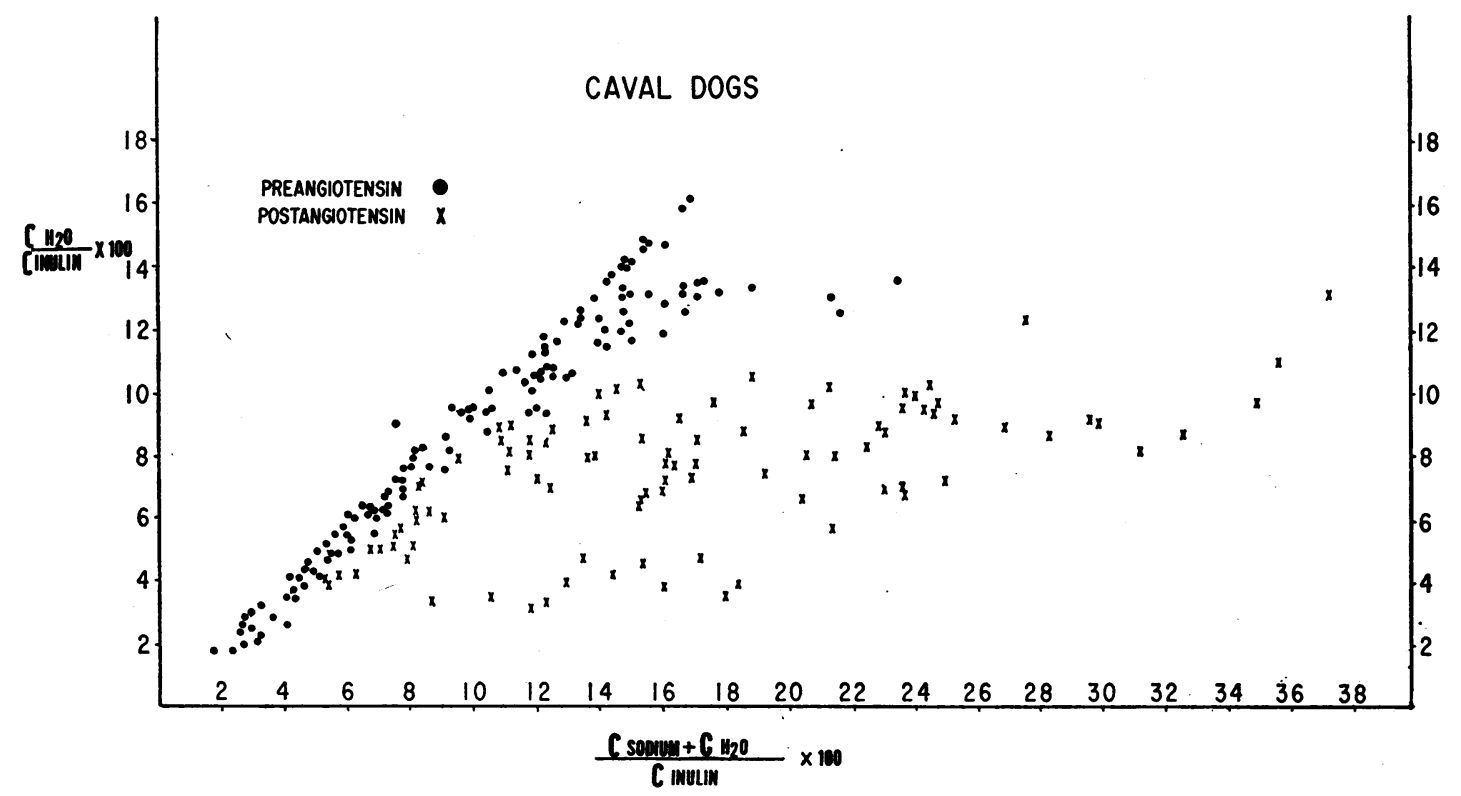

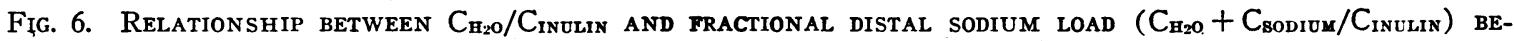
FORE AND AFTER ANGIOTENSIN II IN CAVAL DOGS. The closed circles represent all the clearance periods prior to angiotensin and the $X$ 's represent all the clearance periods after angiotensin in eight experiments during water diuresis and five experiments during hypotonic saline diuresis. 
TABLE III

Effects of a subpressor dose of angiotensin II infused into the left renal artery*

\begin{tabular}{|c|c|c|c|c|c|c|c|c|c|c|c|c|c|c|}
\hline & \multicolumn{2}{|r|}{$\mathrm{V}$} & \multicolumn{2}{|c|}{ Cosm } & \multicolumn{2}{|c|}{$\mathrm{UNaV}_{\mathrm{Na}}$} & \multicolumn{2}{|c|}{$\mathrm{C}_{\mathrm{Na}} / \mathrm{C}_{\mathrm{In}_{\mathrm{n}}}$} & \multicolumn{2}{|c|}{$\mathrm{T}^{\mathrm{c}} \mathrm{H}_{2} \mathrm{O} / \mathrm{C}_{\mathrm{In}}$} & \multicolumn{2}{|c|}{$\mathrm{C}_{\mathbf{I n}}$} & \multicolumn{2}{|c|}{ СРAн } \\
\hline & $\mathbf{R} \ddagger$ & $L \S$ & $\mathbf{R}$ & L & $\mathbf{R}$ & $\mathrm{L}$ & $\mathbf{R}$ & L & $\mathbf{R}$ & $\mathbf{L}$ & $\mathbf{R}$ & L & $\mathbf{R}$ & $\mathrm{L}$ \\
\hline & \multicolumn{2}{|c|}{$m l / m i n$} & \multicolumn{2}{|c|}{$m l / m i n$} & \multicolumn{2}{|c|}{$\mu E q / \min$} & \multicolumn{2}{|c|}{$\begin{array}{c}\% \\
\text { Normal dogs }\end{array}$} & \multicolumn{2}{|c|}{$\%$} & \multicolumn{2}{|c|}{$\operatorname{ml} / \min$} & \multicolumn{2}{|c|}{$\mathrm{ml} / \mathrm{min}$} \\
\hline 1. Control & 1.8 & 2.0 & 2.9 & 3.2 & 67 & 84 & 2.9 & 3.4 & 5.9 & 6.1 & 18.5 & 19.6 & 59 & 63 \\
\hline Angiotensin & 1.9 & 2.1 & 3.1 & 3.3 & 66 & 78 & 2.8 & 3.1 & 6.3 & 6.3 & 19.0 & 20.1 & 61 & 67 \\
\hline 2. Control & 2.3 & 2.1 & 4.1 & 3.7 & 58 & 49 & 1.8 & 1.7 & 6.9 & 6.8 & 26.2 & 23.4 & 107 & 101 \\
\hline Angiotensin & 2.0 & 2.0 & 3.9 & 3.5 & 30 & 55 & 0.9 & 1.9 & 7.2 & 7.0 & 26.5 & 21.5 & 82 & 66 \\
\hline 3. Control & 1.9 & 2.0 & 2.9 & 3.1 & 30 & 42 & 1.5 & 2.1 & 6.0 & 6.4 & 16.6 & 17.1 & 64.8 & 67.7 \\
\hline Angiotensin & 1.9 & 2.0 & 2.9 & 2.9 & 33 & 56 & 1.8 & 3.1 & 6.3 & 5.9 & 16.0 & 15.3 & 52.3 & 44.2 \\
\hline 4. Control & 2.1 & 2.2 & 4.0 & 3.9 & 132 & 111 & 2.8 & 2.8 & 6.4 & 5.9 & 29.9 & 30.4 & 103 & 102 \\
\hline Angiotensin & 2.2 & 1.9 & 3.9 & 3.2 & 131 & 79 & 3.4 & 2.7 & 6.3 & 5.6 & 27.1 & 22.8 & 80 & 73 \\
\hline 5. Control & 1.8 & 1.7 & 2.3 & 2.6 & 54 & 48 & 4.3 & 3.2 & 4.9 & 7.3 & 10.3 & 12.4 & 51.7 & 56.4 \\
\hline Angiotensin & 1.9 & 1.5 & 2.4 & 2.3 & 56 & 55 & 4.7 & 5.0 & 5.1 & 8.9 & 9.9 & 9.0 & 45.3 & 35.8 \\
\hline $\begin{array}{l}\text { Mean control } \\
( \pm \mathrm{SE})\end{array}$ & $\begin{array}{r}2.0 \\
( \pm 0.1)\end{array}$ & $\begin{array}{r}2.0 \\
( \pm 0.1)\end{array}$ & $\begin{array}{r}3.2 \\
( \pm 0.3)\end{array}$ & $\begin{array}{r}3.3 \\
( \pm 0.2)\end{array}$ & $\begin{array}{r}68.2 \\
( \pm 15.0)\end{array}$ & $\begin{array}{r}66.8 \\
( \pm 12.0)\end{array}$ & $\begin{array}{r}2.7 \\
( \pm 0.4)\end{array}$ & $\begin{array}{r}2.6 \\
( \pm 0.3)\end{array}$ & $\begin{array}{r}6.0 \\
( \pm 0.4)\end{array}$ & $\begin{array}{r}6.5 \\
( \pm 0.2)\end{array}$ & $\begin{array}{c}20.3 \\
( \pm 3.0)\end{array}$ & $\begin{array}{c}20.6 \\
( \pm 2.7)\end{array}$ & $\begin{array}{r}77.1 \\
( \pm 10.0)\end{array}$ & $\begin{array}{c}78.0 \\
( \pm 8.7)\end{array}$ \\
\hline $\begin{array}{l}\text { Mean angiotensin } \\
( \pm \mathrm{SE})\end{array}$ & $\begin{array}{r}2.0 \\
( \pm 0.1)\end{array}$ & $\begin{array}{r}1.9 \\
( \pm 0.1)\end{array}$ & $\begin{array}{r}3.2 \\
( \pm 0.3)\end{array}$ & $\begin{array}{r}3.0 \\
( \pm 0.2)\end{array}$ & $\begin{array}{r}63.2 \\
( \pm 17.0)\end{array}$ & $\begin{array}{c}64.7 \\
( \pm 5.0)\end{array}$ & $\begin{array}{r}2.7 \\
( \pm 0.6)\end{array}$ & $\begin{array}{r}3.2 \\
( \pm 0.5)\end{array}$ & $\begin{array}{r}6.2 \\
( \pm 0.3)\end{array}$ & $\begin{array}{c}6.7 \\
( \pm 0.5)\end{array}$ & $\begin{array}{c}19.7 \\
( \pm 2.9)\end{array}$ & $\begin{array}{c}17.7 \\
( \pm 2.3)\end{array}$ & $\begin{array}{c}64.1 \\
( \pm 6.7)\end{array}$ & $\begin{array}{c}57.2 \\
( \pm 6.5)\end{array}$ \\
\hline \multirow[t]{2}{*}{$\begin{array}{l}\text { Mean difference } \\
( \pm \mathbf{S E})\end{array}$} & 0 & $\begin{array}{c}-0.1 \\
( \pm 0.1)\end{array}$ & 0 & $\begin{array}{c}-0.3 \\
( \pm 0.1)\end{array}$ & $\begin{array}{c}-5.0 \\
( \pm 5.0)\end{array}$ & $\begin{array}{c}-2.1 \\
( \pm 7.0)\end{array}$ & 0 & $\begin{array}{c}+0.6 \\
( \pm 0.3)\end{array}$ & $\begin{array}{c}+0.2 \\
( \pm 0.1)\end{array}$ & $\begin{array}{c}+0.2 \\
( \pm 0.3)\end{array}$ & $\begin{array}{c}-0.6 \\
( \pm 0.5)\end{array}$ & $\begin{array}{c}-2.9 \\
( \pm 1.2)\end{array}$ & $\begin{array}{l}-13.0 \\
( \pm 4.5)\end{array}$ & $\begin{array}{l}-20.8 \\
( \pm 5.9)\end{array}$ \\
\hline & & & & & & & \multicolumn{2}{|c|}{ Caval dogs } & & & & & & \\
\hline \multirow{2}{*}{$\begin{array}{l}\text { 6. Control } \\
\text { Angiotensin }\end{array}$} & 1.4 & 1.4 & 2.3 & 2.1 & 15 & 23 & 0.5 & 0.9 & 4.1 & 3.2 & 22.1 & 19.6 & 42.9 & 36.3 \\
\hline & 1.5 & 2.2 & 2.5 & 2.3 & 16 & 91 & 0.6 & 4.8 & 5.0 & 0.7 & 20.0 & 15.1 & 37.6 & 25.4 \\
\hline \multirow{2}{*}{$\begin{array}{l}\text { 7. Control } \\
\text { Angiotensin }\end{array}$} & 1.4 & 1.6 & 2.0 & 2.3 & 6 & 10 & 0.6 & 0.8 & 5.6 & 6.0 & 10.7 & 11.7 & 55.8 & 55.3 \\
\hline & 1.5 & 2.2 & 2.3 & 2.7 & 8 & 106 & 0.6 & 8.9 & 6.6 & 5.0 & 12.2 & 10.0 & 48.3 & 24.0 \\
\hline \multirow{2}{*}{$\begin{array}{l}\text { 8. Control } \\
\text { Angiotensin }\end{array}$} & 2.0 & 1.9 & 3.1 & 3.0 & 98.8 & 101 & 3.8 & 3.9 & 5.4 & 5.5 & 20.2 & 19.9 & 61.4 & 60.9 \\
\hline & 1.7 & 2.6 & 3.0 & 3.3 & 92.2 & 210 & 3.7 & 10.0 & 6.7 & 4.3 & 19.4 & 16.2 & 53.2 & 40.6 \\
\hline \multirow{2}{*}{$\begin{array}{l}\text { 9. Control } \\
\text { Angiotensin }\end{array}$} & 1.4 & 1.8 & 2.7 & 3.3 & 19 & 75 & 0.8 & 2.9 & 6.5 & 7.6 & 20.0 & 19.7 & 65.7 & 64.0 \\
\hline & 1.4 & 2.4 & 2.7 & 3.8 & 18 & 157 & 0.7 & 6.2 & 6.6 & 7.2 & 19.7 & 19.3 & 59.4 & 59.9 \\
\hline \multirow{2}{*}{$\begin{array}{l}\text { 10. Control } \\
\text { Agniotensin }\end{array}$} & 2.8 & 2.5 & 4.4 & 4.0 & 158 & 127 & 4.8 & 3.7 & 6.0 & 5.4 & 26.7 & 27.8 & 80.4 & 79.8 \\
\hline & 2.1 & 2.8 & 3.7 & 3.5 & 75 & 155 & 2.5 & 6.3 & 6.6 & 3.5 & 24.4 & 20.1 & 59.5 & 45.1 \\
\hline $\begin{array}{l}\text { Mean control } \\
\qquad( \pm \mathrm{SE})\end{array}$ & $\begin{array}{r}1.8 \\
( \pm 0.2)\end{array}$ & $\begin{array}{r}1.8 \\
( \pm 0.2)\end{array}$ & $\begin{array}{r}2.9 \\
( \pm 0.4)\end{array}$ & $\begin{array}{r}2.9 \\
( \pm 0.3)\end{array}$ & $\begin{array}{r}59.4 \\
( \pm 26.6)\end{array}$ & $\begin{array}{r}67.2 \\
( \pm 20.0)\end{array}$ & $\begin{array}{c}2.1 \\
( \pm 0.8)\end{array}$ & $\begin{array}{c}2.4 \\
( \pm 0.6)\end{array}$ & $\begin{array}{c}5.5 \\
( \pm 0.4)\end{array}$ & $\begin{array}{c}5.5 \\
( \pm 0.6)\end{array}$ & $\begin{array}{c}19.9 \\
( \pm 2.4)\end{array}$ & $\begin{array}{c}19.7 \\
( \pm 1.9)\end{array}$ & $\begin{array}{c}61.2 \\
( \pm 5.5)\end{array}$ & $\begin{array}{c}59.3 \\
( \pm 6.3)\end{array}$ \\
\hline $\begin{array}{c}\text { Mean angiotensin } \\
( \pm \mathrm{SE})\end{array}$ & $\begin{array}{r}1.6 \\
( \pm 0.1)\end{array}$ & $\begin{array}{r}2.4 \\
( \pm 0.2)\end{array}$ & $\begin{array}{r}2.8 \\
( \pm 0.2)\end{array}$ & $\begin{array}{c}3.1 \\
( \pm 0.2)\end{array}$ & $\begin{array}{r}41.8 \\
( \pm 15.5)\end{array}$ & $\begin{array}{c}144 \\
( \pm 18.5)\end{array}$ & $\begin{array}{r}1.6 \\
( \pm 0.6)\end{array}$ & $\begin{array}{c}7.2 \\
( \pm 0.9)\end{array}$ & $\begin{array}{c}6.3 \\
( \pm 0.8)\end{array}$ & $\begin{array}{c}4.1 \\
( \pm 0.9)\end{array}$ & $\begin{array}{c}19.1 \\
( \pm 1.8)\end{array}$ & $\begin{array}{c}16.1 \\
( \pm 1.7)\end{array}$ & $\begin{array}{l}51.6 \\
(3.6)\end{array}$ & $\begin{array}{c}39.0 \\
( \pm 5.9)\end{array}$ \\
\hline $\begin{array}{c}\text { Mean difference } \\
( \pm \mathrm{SE})\end{array}$ & $\begin{array}{c}-0.2 \\
( \pm 0.1)\end{array}$ & $\begin{array}{l}+0.6 \\
( \pm 0.1)\end{array}$ & $\begin{array}{c}-0.1 \\
( \pm 0.3)\end{array}$ & $\begin{array}{c}+0.2 \\
( \pm 0.6)\end{array}$ & $\begin{array}{c}-17.6 \\
( \pm 14.6)\end{array}$ & $\begin{array}{c}+76.8 \\
( \pm 12.2)\end{array}$ & $\begin{array}{c}-0.5 \\
( \pm 1.0)\end{array}$ & $\begin{array}{c}+4.8 \\
( \pm 0.9)\end{array}$ & $\begin{array}{c}+0.8 \\
( \pm 0.2)\end{array}$ & $\begin{array}{l}-1.4 \\
( \pm 0.3)\end{array}$ & $\begin{array}{c}-0.8 \\
( \pm 0.6)\end{array}$ & $\begin{array}{c}-3.6 \\
( \pm 1.1)\end{array}$ & $\begin{array}{c}-9.6 \\
( \pm 2.5)\end{array}$ & $\begin{array}{l}-20.3 \\
( \pm 5.2)\end{array}$ \\
\hline
\end{tabular}

* Abbreviations are the same as in Table I.

$\ddagger \mathrm{R}$, the right or control kidney.

$\$ \mathrm{~L}$, the left or experimental kidney.

creased on the experimental side in both normal and caval dogs, $14.1 \%$ and $18.3 \%$, respectively. On the control side $\mathrm{C}_{\text {In }}$ fell very slightly. $\mathrm{C}_{\mathbf{P A H}}$ decreased on the experimental side in both groups, $26.7 \%$ in normal dogs and $34.2 \%$ in caval dogs. On the control side $\mathrm{C}_{\mathbf{P A H}}$ also decreased in normal and caval dogs, $16.9 \%$ and $15.7 \%$, respectively. In no instance was there a measurable increase in blood pressure.

\section{Discussion}

The present experiments clearly establish that angiotensin causes a greater inhibition of renal tu- bular sodium reabsorption in caval dogs than in normal dogs. This difference was still apparent when the natriuretic action of angiotensin was augmented in normal dogs by water or hypotonic saline diuresis. The greater response in caval dogs cannot be attributed to hyperaldosteronism or hyperangiotensinemia, since salt-depleted normal dogs with similar increases in aldosterone secretion and circulating angiotensin (24) had no natriuretic response to angiotensin. In addition, acute (15) and chronic ${ }^{3}$ aldosterone administration in

3 Porush, J. G., and S. M. Rosen. Unpublished observations. 
NORMAL DOGS

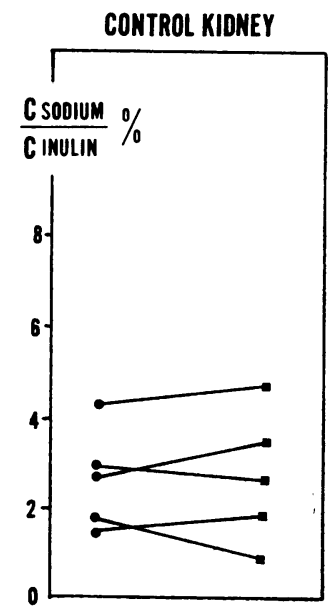

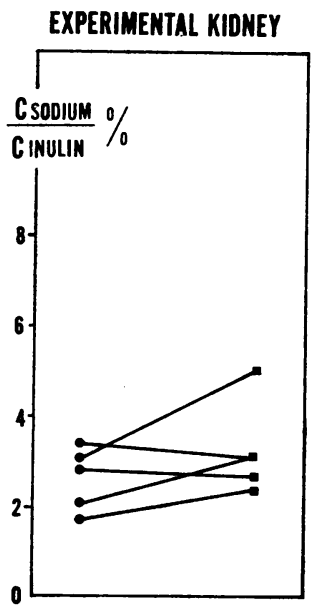

CONTROL •
CAVAL DOGS
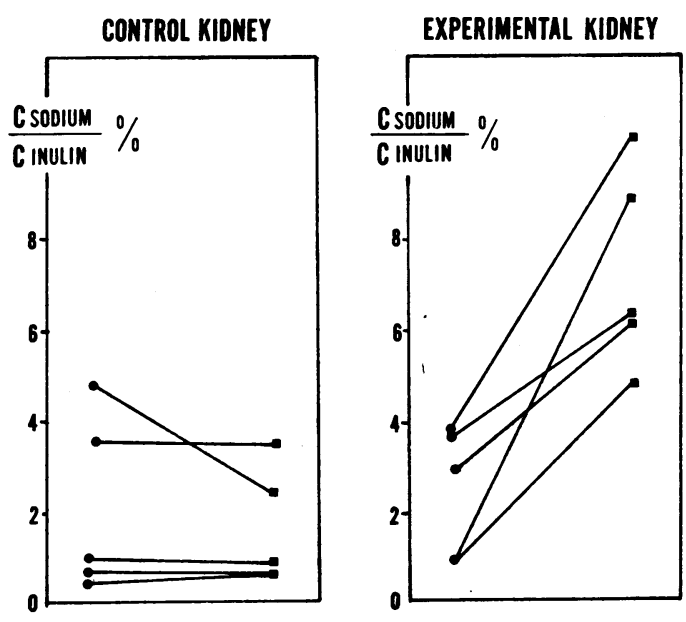

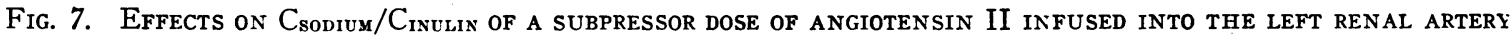
OF NORMAL AND CAVAL DOGS. The experimental kidney is the infused left kidney and the control kidney represents the right kidney. The control and angiotensin periods are defined as in Fig. 1.

normal dogs does not lead to an augmented natriuretic response to angiotensin.

Some investigators $(5,14)$ have suggested that the natriuretic action of angiotensin is unmasked in normal dogs under anesthesia or while undergoing an osmotic diuresis as a consequence of the reduced renal vasoconstricting action of angiotensin (as manifest by attenuated falls in GFR and ERPF) seen in these experimental modifications. Cannon et al. (14) also suggested that the natriuretic response of caval dogs could be explained by the same mechanism. Blunting of the renal vasoconstricting effects of angiotensin by anesthesia (and possibly by the infusion of mannitol) may be partially responsible for unmasking the natriuretic response during the hydropenic experiments. Further diminution of the renal vasoconstricting effect of angiotensin may account, in part, for the augmented response during water and hypotonic saline diuresis and appears to play a role in the augmented response of caval dogs. However, it is also apparent from the present experiments that this mechanism does not fully explain the greater natriuretic response in caval dogs. Moreover, the natriuretic action of angiotensin was not always associated with attenuation of the constricting effect on renal blood vessels or correlated with the degree of blunting. In those experiments in which angiotensin was infused directly into the renal artery significant vasoconstriction was apparent in both normal and caval dogs as evidenced by the decreases in GFR and ERPF (with greater falls in caval dogs) (Table III), yet an ipsilateral natriuresis was still noted in both groups with a much greater effect in caval dogs. In addition, the most striking difference in the natriuretic response between caval and normal dogs was noted during the hydropenic experiments where the effects on GFR and ERPF were not significantly different. Finally, the greater response during hypotonic saline diuresis compared to water diuresis was not associated with significantly different renal hemodynamic effects in either normal or caval dogs.

It has been suggested that an extrarenal circulatory alteration is necessary for the angiotensin natriuresis $(14,25)$. It is possible, therefore, that differences in the systemic pressor response to angiotensin may account for the augmented natriuresis in caval dogs as well as during water or hypotonic saline diuresis. However, the intrarenal artery infusion experiments demonstrate that a subpressor dose of angiotensin is effective in producing an ipsilateral natriuresis, with an augmented response still present in caval dogs. Furthermore, in most instances there was no correlation between the extent of the natriuresis and the 
degree of blood pressure elevation produced by systemic administration of angiotensin. Only in salt-depleted normal dogs and in normal dogs undergoing a saline diuresis did it appear that the systemic pressor action of angiotensin played a role (Tables I and II). Nevertheless, it seems clear that angiotensin has a direct renal action independent of an extrarenal circulatory alteration.

Whether the renal effect of angiotensin is due to direct interference with a sodium transport system in the tubule or mediated by an alteration in intrarenal hemodynamics is not clear. Although both proposals are possible, the latter seems more compatible with the known vasoactive properties of angiotensin. Accordingly, it is possible that the increased natriuretic response in both normal and caval dogs during water diuresis compared to the hydropenic state and the further augmentation during hypotonic saline diuresis may be related to an alteration in intrarenal hemodynamics. In this regard, an increase in medullary blood flow has been demonstrated during these diuretic states $(26,27)$. Therefore, it may be conjectured that water and saline loading condition the kidney to the natriuretic action of angiotensin by their effects on intrarenal blood flow in addition to attenuating or preventing the fall in GFR and ERPF. It may be further postulated that dogs with thoracic inferior vena cava constriction and ascites have a similar alteration of intrarenal blood flow (perhaps due to extracellular volume expansion which also occurs during water and saline loading) accounting for the augmented natriuretic response to angiotensin in these dogs.

The consistent increase in potassium excretion as sodium excretion increased (Tables I and II) places the action of angiotensin proximal to the sodium-potassium exchange site in the distal tubule. In an attempt to localize the site of action of angiotensin more precisely, we performed the present experiments under maximal hydropenia or water diuresis so that the effects on $\mathrm{T}_{\mathrm{H}_{2} \mathrm{O}}$ and $\mathrm{C}_{\mathrm{H}_{2} \mathrm{O}}$ could be assessed. During hydropenia the natriuresis noted in normal dogs and the decrease in $\mathrm{T}^{\mathrm{c}_{\mathrm{H}_{2} \mathrm{O}}}$ were too small to evaluate with any confidence. In caval dogs, however, a significant decrease in $\mathrm{T}^{\mathrm{c}} \mathrm{H}_{2} \mathrm{O}$ was noted after angiotensin, a decrease which correlated with the degree of natriuresis and chronologically paralleled the natriuretic effect, suggesting that the fall in $\mathrm{T}^{\mathrm{c}}{ }_{\mathrm{H}_{2} \mathrm{O}}$ was directly related to the inhibition of tubular sodium reabsorption and not to an independent action on urine concentration.

Insofar as $\mathrm{T}^{\mathrm{c}} \mathrm{H}_{2} \mathrm{O}$ is determined by medullary hypertonicity, which is dependent in large part on sodium reabsorption at the ascending limb of Henle's loop (28-32), the fall in $\mathrm{T}^{\mathbf{c}} \mathrm{H}_{2} \mathrm{O}$ accompanying the natriuresis in caval dogs is best explained by the inhibition of sodium reabsorption at this site. An alternate hypothesis would place the locus of action of angiotensin in the proximal tubule, with the fall in $\mathrm{T}_{\mathbf{H}_{2} \mathrm{O}}$ explained by the entrance into the collecting duct of a large volume of hypotonic fluid such that $\mathrm{T}^{\mathrm{c}} \mathrm{H}_{2} \mathrm{O}$ decreases even though solute-free water is abstracted at increasing rates at this site $(33,34)$. This mechanism may be responsible for the fall in $\mathrm{T}^{c_{\mathrm{H}_{2} \mathrm{O}}}$ and the dilute urine sometimes obtained after angiotensin in salt restricted caval dogs, where $\mathrm{T}^{\mathbf{c}}{ }_{\mathrm{H}_{2} \mathrm{O}}$ tended to fall at relatively low rates of solute excretion even before angiotensin administration (Fig. 2). However, it is unlikely that this mechanism accounts for the decrease in $\mathrm{T}^{\mathrm{c}}{ }_{\mathrm{H}_{2} \mathrm{O}}$ noted in caval dogs on a regular diet, since $\mathrm{T}^{\mathbf{c}}{ }_{\mathrm{H}_{2} \mathrm{O}}$ was usually still rising at the time of angiotensin administration, and in no experiment was a dilute urine formed (Fig. 1). In addition, during mannitol diuresis the increased delivery of sodium to the loop of Henle was generally associated with an increase in $\mathrm{T}^{\mathrm{c}}{ }_{\mathrm{H}_{2} \mathrm{O}}$ over the same range of $\mathrm{C}_{\mathrm{osm}}$ associated with a fall in $\mathrm{T}_{\mathrm{H}_{2} \mathrm{O}}^{\mathrm{O}}$ when produced by angiotensin (Fig. 3).

If the entire natriuresis observed with angiotensin was derived from the ascending limb, it might be expected that medullary hypertonicity and $\mathrm{T}^{\mathrm{c}}{ }_{\mathrm{H}_{2} \mathrm{O}}$ formation would be largely eliminated in those experiments in which a large increase in sodium excretion was noted. In no instance, however, did this occur in caval dogs on a regular diet, including experiments in which the increase in fractional sodium excretion was $10 \%$ or greater (Fig. 1). This suggests that angiotensin inhibits sodium reabsorption at a site in addition to the ascending limb. On the basis of alterations in $\mathrm{T}^{\mathrm{c}} \mathrm{H}_{2} \mathrm{O}$ it is not possible to distinguish between the proximal and distal tubule as the additional site in the presence of a partial block at the ascending limb.

During water diuresis and hypotonic saline diuresis angiotensin appeared to place a limit on the 
capacity of both normal and caval dogs to excrete free water (Figs. 4-6). This limitation resembles the effect of furosemide on $\mathrm{C}_{\mathrm{H}_{2} \mathrm{O}}$ reported by Suki et al. (35). If the diluting segment of the nephron is divided into two sites, a medullary and cortical portion, as proposed by these authors, then the results suggest that angiotensin blocks one site, leaving the other available to generate free water. Taken in conjunction with a decrease in $\mathrm{T}^{\mathrm{c}}{ }_{\mathrm{H}_{2} \mathrm{O}}$, a block in the medullary diluting segment or ascending limb of Henle's loop would have to be postulated.

Inhibition of sodium reabsorption in the proximal tubule may be explored during water diuresis by examining the effects of angiotensin on distal sodium load. If it is assumed that free water is formed primarily by the reabsorption of sodium at water impermeable segments, then the sum of $\mathrm{C}_{\mathrm{Na}}$ $+\mathrm{C}_{\mathrm{H}_{2} \mathrm{O}}$ can be used as an approximation of the amount of sodium leaving the proximal tubule. During water and hypotonic saline diuresis distal sodium load increased in every instance after angiotensin, pointing to a proximal action of angiotensin. It is possible that inhibition of sodium reabsorption in the ascending limb could decrease water reabsorption from the descending limb and collecting duct $(26,35)$, thereby making the sum of $\mathrm{C}_{\mathrm{Na}}+\mathrm{C}_{\mathrm{H}_{2} \mathrm{O}}$ greater than control without a true increase in the amount of sodium leaving the proximal tubule. However, the increase in distal sodium load was almost exclusively due to an increase in sodium clearance which frequently exceeded $20 \%$ of the filtered load after angiotensin. Although this degree of natriuresis might still be accounted for by a block at the diluting segments, it seems unlikely that $\mathrm{C}_{\mathrm{H}_{2} \mathrm{O}}$ could be maintained at $8-10 \%$ of the glomerular filtrate when more than $20 \%$ of the filtered sodium was excreted if the inhibition occurred at the diluting segments only. Thus, by examining the effects of angiotensin on water excretion during hydropenia and water diuresis, it is concluded that in the dog angiotensin inhibits sodium reabsorption in the proximal tubule and ascending limb of Henle's loop.

In normal and caval dogs the effect of angiotensin on $\mathrm{C}_{\mathrm{H}_{2} \mathrm{O}}$ was essentially the same. This could indicate a similar degree of block at the diluting segment with the greater natriuretic effect of angiotensin in caval dogs derived primarily from a greater degree of interference with sodium reab- sorption in the proximal tubule. Since an increase in proximal tubular sodium reabsorption has been demonstrated after constriction of the thoracic inferior vena cava (36), it is possible that the greater natriuresis in caval dogs is due, in part, to the antagonism of this salt-retaining mechanism by angiotensin.

\section{Acknowledgments}

We gratefully acknowledge the invaluable technical assistance of Miss Juanita Kennebrew and Mr. George Griffiths and the secretarial help of Mrs. Pauline Baker.

\section{References}

1. Hughes-Jones, N. C., G. W. Pickering, P. H. Sanderson, H. Scarborough, and J. Vandenbroucke. 1949. The nature of the action of renin and hypertensin on renal function in the rabbit. J. Physiol. (London). $109: 288$.

2. Peters, G. 1963. Renal tubular effect of vals-angiotensin II amide in rats. Proc. Soc. Exptl. Biol. Med. $112: 771$.

3. Gross, F., and H. Turrian. 1960. Pharmacology of hypertensin and similar analogues. In Polypeptides which affect smooth muscles and blood vessels. M. Schachter, editor. Pergammon Press, New York. 137.

4. Vander, A. J. 1963. Inhibition of distal tubular sodium reabsorption by angiotensin II. Am. J. Physiol. 205 : 133.

5. Levitin, H., W. B. Lehmann, G. Pigeon, Y. Warren, and I. S. Goldenberg. 1963. The effect of anesthesia and adrenalectomy on renal response to angiotensin. J. Clin. Invest. 42 : 951.

6. Pickering, G. 1964. Action of renin and angiotensin in the renal handling of sodium and chloride in rabbits. Can. Med. Assoc. J. 90: 256.

7. Healy, J. K., C. Barcena, J. M. B. O'Connell, and G. E. Schreiner. 1965. Renal and pressor action of angiotensin in the normal dog. Am. J. Physiol. 208: 1093.

8. Louis, W. J., and A. E. Doyle. 1965. The effects of varying doses of angiotensin on renal function and blood pressure in man and dogs. Clin. Sci. 29 : 489.

9. Laragh, J. H., P. J. Cannon, C. J. Bentzel, A. M. Sicinski, and J. I. Meltzer. 1963. Angiotensin II, norepinephrine, and renal transport of electrolytes and water in normal man and in cirrhosis with ascites. J. Clin. Invest. 42: 1179.

10. Biron, P., M. Chretien, E. Koiw, and J. Genest. 1962. Effects of angiotensin infusions on aldosterone and electrolyte excretion in normal subjects and patients with hypertension and adrenocortical disorders. Brit. Med. J. 1 : 1569.

11. Dustan, H., C. Nijenson, and A. C. Corcoran. 1955. Natriuretic-diuretic effect of angiotonin in essential hypertension. J. Clin. Invest. 34: 931. 
12. Brown, J. J., and W. S. Peart. 1962. The effect of angiotensin on urine flow and electrolyte excretion in hypertensive patients. Clin. Sci. 22: 1.

13. Kaplan, N. M., and J. G. Silah. 1964. The effect of angiotensin II on the blood pressure in humans with hypertensive disease. J. Clin. Invest. 43: 659.

14. Cannon, P. J., R. P. Ames, and J. H. Laragh. 1966. Indirect action of angiotensin infusion to inhibit renal tubular sodium reabsorption in dogs. $A m$. J. Physiol. 211 : 1021.

15. Healy, J. K., J. B. Suszkiw, V. W. Dennis, and G. E. Schreiner. 1966. Effect of aldosterone and salt intake on renal and pressor actions of angiotensin. Nephron. 3 : 329.

16. Porush, J. G., and S. M. Rosen. 1965. The effects of angiotensin II in normal dogs and in dogs with thoracic inferior vena cava constriction. Clin. Res. 13: 312 .

17. Porush, J. G., G. J. Kaloyanides, R. J. Cacciaguida, and S. M. Rosen. 1966. Effects of angiotensin II in normal and caval dogs during water diuresis. Clin. Res. 14 : 385.

18. Davis, J. O., and D. S. Howell. 1953. Mechanism of fluid and electrolyte retension in experimental preparations in dogs. II. With thoracic inferior vena cava constriction. Circulation Res. 1: 171.

19. Eisner, G. M., J. G. Porush, M. H. Goldstein, and M. F. Levitt. 1962. An appraisal of free water reabsorption $\left(\mathrm{T}^{\mathbf{c}}{ }_{\mathrm{H}_{2} \mathrm{O}}\right.$ ) in man. J. Mt. Sinai. Hosp. N. Y. $29: 38$.

20. Schales, O., and S. S. Schales. 1941. A simple and accurate method for the determination of chloride in biological fluids. J. Biol. Chem. 140:879.

21. Cotlove, E., H. V. Trantham, and R. L. Bowman. 1958. An instrument and method for automatic, rapid, accurate and sensitive titration of chloride in biological samples. J. Lab. Clin. Med. 51: 461.

22. Schreiner, G. E. 1950. Determination of inulin by means of resorcinol. Proc. Soc. Exptl. Biol. Med. 74 : 117.

23. Smith, H. W., N. Finkelstein, L. Aliminosa, B. Crawford, and M. Graber. 1945. The renal clearances of substituted hippuric acid derivatives and other aromatic acids in dogs and man. J. Clin. Invest. $24: 388$.

24. Davis, J. O., P. M. Hartroft, E. O. Titus, C. C. J. Carpenter, C. R. Ayers, and H. E. Spiegel. 1962. The role of the renin-angiotensin system in the control of aldosterone secretion. J. Clin. Invest. $41: 378$.

25. Earley, L. E. 1966. Influence of hemodynamics factors on sodium reabsorption. Ann. N.Y. Acad. Sci. $139: 312$.

26. Earley, L. I., and R. M. Friedler. 1965. Changes in renal blood flow and possibly the intrarenal distribution of blood during the natriuresis accompanying saline loading in the dog. J. Clin. Invest. 44 : 929.

27. Ullrich, K. J., K. Kramer, and J. W. Boylan. 1961. Present knowledge of the counter-current system in the mammalian kidney. Progr. Cardiovascular Diseases. $3: 395$.

28. Berliner, R. W., N. G. Levinsky, D. G. Davidson, and M. Eden. 1958. Dilution and concentration of the urine and the action of antidiuretic hormone. $\mathrm{Am}$. J. Med. $24: 730$.

29. Wirz, H. 1957. The location of antidiuretic action in the mammalian kidney in The Neurohypophysis. H. Heller, editor. Academic Press Inc., New York. 157.

30. Gottschalk, C. W., and M. Mylle. 1959. Micropuncture study of the mammalian urinary concentrating mechanism: evidence for the countercurrent hypothesis. Am. J. Physiol. 196: 927.

31. Levinsky, N. G., D. G. Davidson, and R. W. Berliner. 1959. Effects of reduced glomerular filtration on urine concentration in the presence of antidiuretic hormone. J. Clin. Invest. 38: 730.

32. Porush, J. G., M. H. Goldstein, G. M. Eisner and M. F. Levitt. 1961. Effect of organomercurials on the renal concentrating operation in hydropenic man: comments on site of action. J. Clin. Invest. 40: 1475 .

33. Earley, L. E., M. Kahn, and J. Orloff. 1961. The effects of infusions of chlorothiazide on urinary dilution and concentration in the dog. J. Clin. Invest. $40: 857$.

34. Clapp, J. R., and R. R. Robinson. 1966. Osmolality of distal tubular fluid in the dog. J. Clin. Invest. $45: 1847$.

35. Suki, W., F. C. Rector, Jr., and D. W. Seldin. 1965. The site of action of furosemide and other sulfonamide diuretics in the dog. J. Clin. Invest. $44: 1458$.

36. Cirksena, W. J., J. H. Dirks, and R. W. Berliner. 1966. Effect of thoracic cava obstruction on response of proximal tubule sodium reabsorption to saline infusion. J. Clin. Invest. 45 : 179. 